\title{
9. GEOCHEMISTRY AND PETROLOGY OF BASALTS FROM LEG 136, CENTRAL PACIFIC OCEAN ${ }^{1}$
}

\author{
Alan J. King, ${ }^{2}$ D. Guy Waggoner, ${ }^{3}$ and Michael O. Garcia ${ }^{2}$
}

\begin{abstract}
About $13 \mathrm{~m}$ of Cretaceous, tholeiitic basalt, ranging from normal (N-MORB) to transitional (T-MORB) mid-ocean-ridge basalts, was recovered at Ocean Drilling Program Site 843 west of the island of Hawaii. These moderately fractionated, aphyric lavas are probably representative of the oceanic basement on which the Hawaiian Islands were built. Whole-rock samples from parts of the cores exhibiting only slight, low-temperature, seawater alteration were analyzed for major element, trace element, and isotopic composition. The basalts are characterized by enrichment in the high field strength elements relative to N-MORB, by a distinct positive $\mathrm{Eu}$ anomaly, and by $\mathrm{Ba} / \mathrm{Nb}$ and $\mathrm{La} / \mathrm{Nb}$ ratios that are much lower than those of other crustal or mantle-derived rocks, but their isotope ratios are similar to those of present-day N-MORB from the East Pacific Rise. Hole 843A lavas are isotopically indistinguishable from Hole 843B lavas and are probably derived from the same source at a lower degree of partial melting, as indicated by lower $\mathrm{Y} / \mathrm{Nb}$ and $\mathrm{Zr} / \mathrm{Nb}$ ratios and by higher concentrations of light and middle rare earth elements and other incompatible elements relative to Hole 843B lavas. Petrographic and trace-element evidence indicates that the Eu anomaly was the result of neither plagioclase assimilation nor seawater alteration. The Eu anomaly and the enrichments in Ta, $\mathrm{Nb}$, and possibly $\mathrm{U}$ and $\mathrm{K}$ relative to $\mathrm{N}$-MORB apparently are characteristic of the mantle source. Age-corrected $\mathrm{Nd}$ and $\mathrm{Sr}$ isotopic ratios indicate that the source for the lavas recovered at ODP Site 843 was similar to the source for Southeast Pacific MORB. An enriched component within the Cretaceous mantle source of these basalts is suggested by their initial ${ }^{208} \mathrm{~Pb} /{ }^{204} \mathrm{~Pb}-{ }^{206} \mathrm{~Pb} /{ }^{204} \mathrm{~Pb}$ and $\varepsilon_{\mathrm{Nd}}{ }^{206} \mathrm{~Pb} /{ }^{204} \mathrm{~Pb}$ ratios. The $\mathrm{Sr}-\mathrm{Pb}$ isotopic trend of Hawaiian post-shield and post-erosional lavas cannot be explained by assimilation of oceanic crust with the isotopic composition of the Site 843 basalts.
\end{abstract}

\section{INTRODUCTION}

Ocean Drilling Program (ODP) Site 843 represents the first successful attempt to drill oceanic crust basement in the vicinity of the Hawaiian Islands. Previous attempts were made during Deep Sea Drilling Project (DSDP) Legs 6 and 7. Site 843 is located on the Hawaiian Arch about $320 \mathrm{~km}$ west of the island of Hawaii (Fig. 1). The basalts recovered at this location are probably representative of the oceanic crust through which hot spot magmas have ascended to form the Hawaiian island chain. About $13 \mathrm{~m}$ of basalt core was recovered at five intervals from a 70-m penetration of basement in two holes at Site 843. The lavas range in composition from normal to transitional midocean-ridge basalts (MORB). Nannofossils in sediment directly overlying the basalt assign a minimum age to the lava of late Albian to early Cenomanian (94-100 Ma; Firth, this volume). $\mathrm{An}^{40} \mathrm{Ar}{ }^{39} \mathrm{Ar}$ date of the basalt yields an age of $110 \pm 2 \mathrm{Ma}$ (Waggoner, this volume). Paleomagnetic studies of basaltic cores from Site 843 indicate a paleolatitude of about $10^{\circ} \mathrm{S}$ (Helsley, this volume). This latitude on the East Pacific Rise (EPR) is in general agreement with past Pacific plate motion as deduced from the Hawaiian hot spot trace (e.g., Pringle, 1992).

This chapter characterizes the geochemistry of the Cretaceous basement basalt cored at Site 843, and compares these lavas with present-day MORB from the EPR. The hypothesis of oceanic crustal contamination of Hawaiian magmas proposed in earlier studies to explain geochemical variations in Hawaiian lavas (e.g., Clague and Frey, 1982; Chen and Frey, 1983, 1985; West et al., 1987) is tested using geochemical data from Site 843 basalts rather than zero-age EPR basalt data as in previous studies. The earlier studies concluded that Hawaiian post-shield and post-erosional magmas assimilated a depleted-mantle end member, presumably the source for Pacific MORB (Chen and Frey, 1985). The present study shows that Site 843 basement basalts will not serve as a depleted-mantle end member for these isotope-based, magma-mixing or assimilation models. Site 843

\footnotetext{
${ }^{1}$ Wilkens, R.H.,Firth, J., Bender, J., et al., 1993. Proc. ODP, Sci. Results, 136: College Station, TX (Ocean Drilling Program).

${ }^{2}$ Geology and Geophysics Department, University of Hawaii, Honolulu, HI 96822 , U.S.A.

${ }^{3}$ Hawaii Institute of Geophysics, University of Hawaii, Honolulu, HI 96822, U.S.A.
}

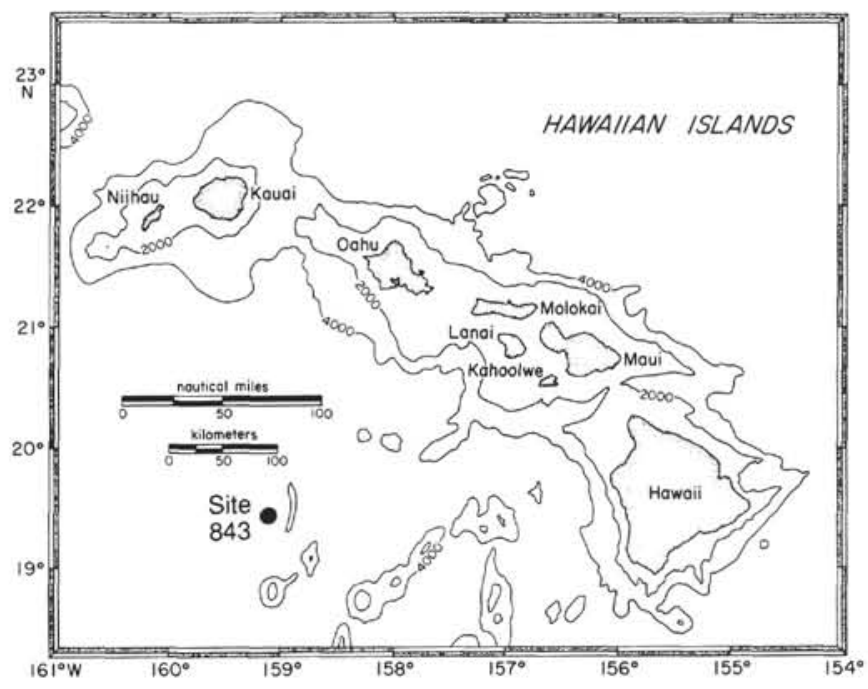

Figure 1. Map of Hawaiian Islands showing location of Site 843. Bathymetric contours in meters.

lavas differ greatly in trace element composition from most Pacific MORB, so that the source for this Cretaceous MORB was similar isotopically but distinct in high field strength elements (HFSE) when compared with present-day EPR lavas.

\section{SAMPLING}

Figure 2 shows the intervals drilled and cored at Holes 843A and $843 \mathrm{~B}$. Hole $843 \mathrm{~A}$ penetrated about $3 \mathrm{~m}$ into basement on a small, northwest-trending ridge south of the Molokai fracture zone. The ridge rises 60 to $70 \mathrm{~m}$ above the regional abyssal plain and is interpreted to be part of an abyssal hill fabric (Shipboard Scientific Party, 1992b), based on the site survey (Collins et al., 1992). About $60 \mathrm{~cm}$ of aphyric, pillow basalt core was recovered from Hole 843A, including the sediment/basalt contact. At this contact, the basalt is pillowed 
with an altered, formerly glassy margin. Below this margin, the basalt is massive and moderately altered (see Alt, this volume).

Hole $843 \mathrm{~B}$ was drilled about $10 \mathrm{~m}$ from Hole $843 \mathrm{~A}$; it penetrated $70 \mathrm{~m}$ into basement. Approximately $12.6 \mathrm{~m}$ of basalt was recovered over a $43.7-\mathrm{m}$ interval, starting about $17 \mathrm{~m}$ below the sediment/basalt contact (Fig. 2), which is about $13.7 \mathrm{~m}$ deeper than the sediment/basalt contact in Hole 843A (Shipboard Scientific Party, 1992b). The basalt is aphyric and massive, like that cored in Hole 843A, and has been fractured and locally brecciated. Alteration appears most extensive around the fractures.

Whole-rock samples for chemical analyses were chosen from the macroscopically freshest-looking, light gray, massive basalt available at representative intervals in the core. These light gray portions of the basalt core were determined by Alt (this volume) to be the least-altered areas of the core. Seen in thin section, these samples are holocrystalline, but olivine is altered to iddingsite. Clays, Fe-oxyhydroxides, and other secondary minerals are generally confined to veins, fractures, and vesicles, and were avoided in our sample selection, with the exception of one sample. Sample 136-843B-2R-2, 77-79 cm, was chosen for analysis because of its visible alteration.

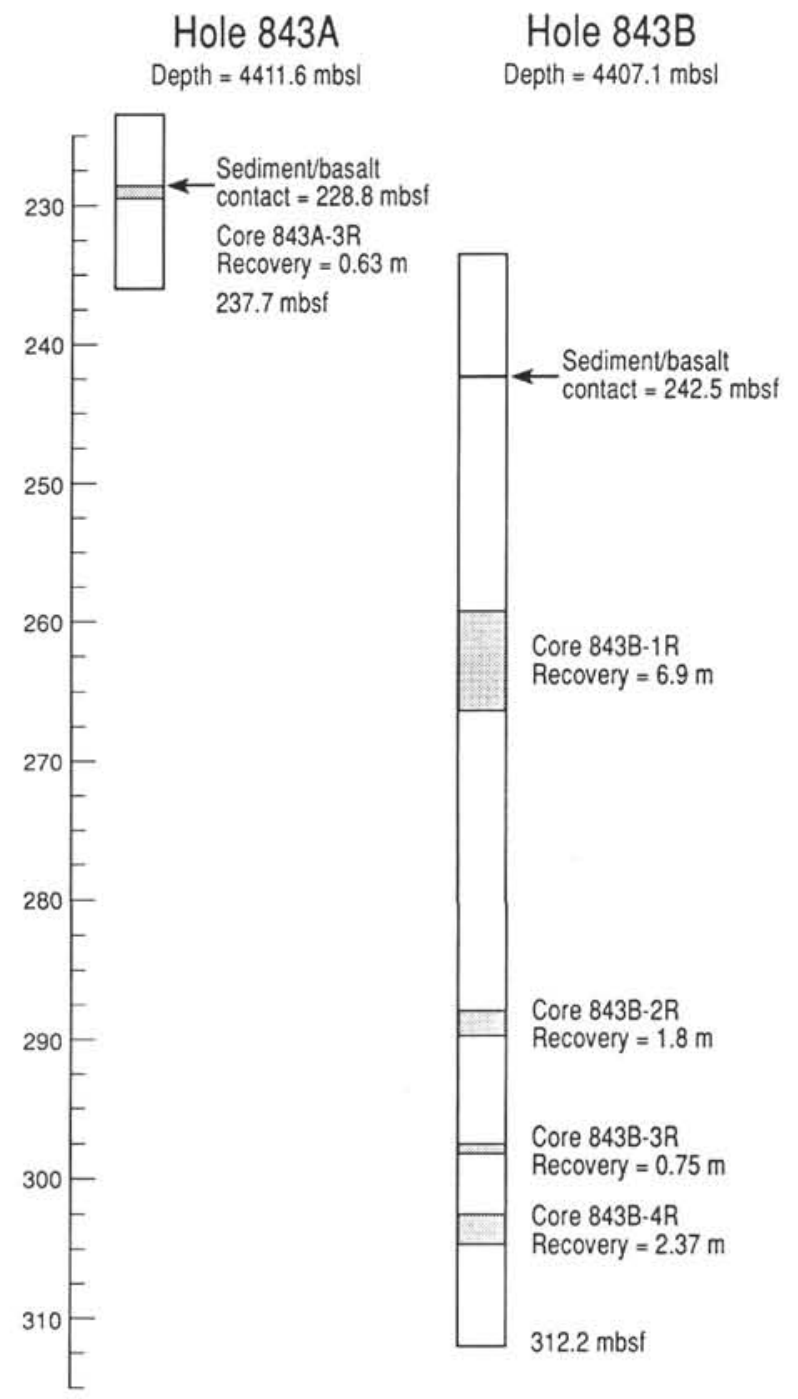

Figure 2. Schematic diagram of basement basalts drilled at Holes $843 \mathrm{~A}$ and 843B, after Shipboard Scientific Party (1992b). Stippled areas indicate intervals of basalt recovery $. \mathrm{mbsl}=$ meters below sea level $. \mathrm{mbsf}=$ meters below seafloor.

\section{ANALYTICAL METHODS}

Petrographic methods and terminology used in descriptions of cores and thin sections are as noted in Shipboard Scientific Party (1992a).

Major element oxides (Table 1) were analyzed on board JOIDES Resolution by X-ray fluorescence (XRF) using a fully automated, wavelength-dispersive ARL 8420 system with a Rh target X-ray tube. Whole-rock sample preparation, ignition, lanthanum doping, fusion, and analysis were performed as described in Shipboard Scientific Party (1992a). Replicate analyses show major element data are precise within $0.5 \%-2.5 \%$ and are considered accurate to about $1 \%$ for $\mathrm{Si}, \mathrm{Ti}, \mathrm{Fe}, \mathrm{Mg}, \mathrm{Ca}$, and $\mathrm{K}$, and to between $3 \%$ and $5 \%$ for $\mathrm{Al}, \mathrm{Mn}, \mathrm{Na}$, and P. Results of measurements of the USGS Hawaiian basalt standard BHVO-1 are given in Shipboard Scientific Party (1992a). A few samples, denoted in Table 1, were analyzed for major elements at the University of Hawaii on a fully automated, wavelength-dispersive Siemens SRS 303 AS instrument with a Rh target X-ray tube, following the method of Norrish and Hutton (1969).

XRF determination of trace element abundances of Sc, V, Cr, Co, $\mathrm{Ni}, \mathrm{Cu}, \mathrm{Zn}, \mathrm{Sr}, \mathrm{Y}, \mathrm{Zr}$, and $\mathrm{Nb}$ (Table 2) was done at the University of Hawaii on a fully automated, wavelength-dispersive Siemens SRS 303 AS instrument with a Rh target X-ray tube, following the method of Norrish and Chappell (1977). Each whole-rock sample taken adjacent to those used for major element analysis was prepared for trace element analysis by grinding off saw and drill marks and ultrasonically rinsing off excess Al grit. The dried sample was then crushed between motordriven tungsten carbide plates into 2- to $5-\mathrm{mm}$ pieces. The powder made during the crushing process was not used for analysis to minimize the possibility of $\mathrm{Nb}$ and Co contamination from tungsten carbide. The rock is essentially aphyric, so the 2- to 5 - $\mathrm{mm}$ pieces are thought to be representative of the whole rock. The pieces were ultrasonically washed in $2 \mathrm{~N} \mathrm{HCl}$ for $2-3 \mathrm{hr}$ to remove surface contaminants, then rinsed ultrasonically twice at $2-3 \mathrm{hr}$ per rinse. The dried sample, weighing 7-9 g, was powdered in an $\mathrm{Al}_{2} \mathrm{O}_{3}$ ball mill for 20-30 min. Final powdering was done in an agate mortar to ensure consistent and thorough powdering of all samples. A pressed powder pellet was prepared from each sample from $5.5 \mathrm{~g}$ of whole-rock powder, by moistening the powder with 8 or 9 drops of polyvinyl alcohol solution and pressing the moistened powder into a cylinder. The sides and bottom of the powder cylinder are surrounded with boric acid, and pressed in a ring press at 2.5-3.0 tons for 1-2 $\mathrm{min}$.

Abundances of $\mathrm{Rb}, \mathrm{Cs}, \mathrm{Ba}, \mathrm{Hf}, \mathrm{Ta}, \mathrm{Th}, \mathrm{U}$, and all 14 stable rare earth elements (REE) (Table 3 ) were determined by inductively coupled plasma mass spectrometry (ICP-MS) at Washington State University, using splits of the same whole-rock powders prepared for trace element XRF analyses. For each sample, $200 \mathrm{mg}$ of powder was dissolved on a hot plate at $110^{\circ} \mathrm{C}$ using $\mathrm{HF}, \mathrm{HNO}_{3}$, and $\mathrm{HClO}_{4}$ in an open Teflon vial. The sample was evaporated to dryness, then evaporated again with $\mathrm{HClO}_{4}$ at $165^{\circ} \mathrm{C}$ to convert insoluble fluorides to soluble perchlorates. An In-Re internal standard was used to monitor drift. The samples were analyzed using a Sciex Elan 250 ICP-MS with cross-flow nebulizer, water-cooled torch, and Brooks mass flow controllers. Oxide interference corrections were determined for each run using two solutions prepared from single-element standards. Sample intensities were first corrected for isobaric and oxide interferences, then for instrumental drift using a mass-weighted average of the drift of In and Re (after Doherty, 1989). The elemental intensities were calibrated from a curve constructed from three "in-house" standards that were dissolved with the unknowns. The USGS Hawaiian basalt standard, BHVO-1, was run as an internal control with the unknowns. The results for BHVO-1, as well as its consensus trace element abundances, are shown in Table 3 . The results agree with the consensus values for most elements.

$\mathrm{Sr}, \mathrm{Nd}$, and $\mathrm{Pb}$ isotopic ratios and abundances of $\mathrm{Sr}, \mathrm{Rb}, \mathrm{Sm}, \mathrm{Nd}$, and $\mathrm{Pb}$ (Table 4) were determined at the University of Hawaii on a multicollector VG Sector solid-source mass spectrometer. Saw and drill marks were ground off whole-rock samples taken adjacent to those 
Table 1. Major element abundances in Site 843 basalts determined by XRF.

\begin{tabular}{|c|c|c|c|c|c|c|c|c|c|c|c|c|}
\hline $\begin{array}{l}\text { Core, section, } \\
\text { interval }(\mathrm{cm})\end{array}$ & $\mathrm{SiO}_{2}$ & $\mathrm{TiO}_{2}$ & $\mathrm{Al}_{2} \mathrm{O}_{3}$ & $\mathrm{Fe}_{2} \mathrm{O}_{3}$ & $\mathrm{MnO}$ & $\mathrm{MgO}$ & $\mathrm{CaO}$ & $\mathrm{Na}_{2} \mathrm{O}$ & $\mathrm{K}_{2} \mathrm{O}$ & $\mathrm{P}_{2} \mathrm{O}_{5}$ & Total & LOI \\
\hline \multicolumn{13}{|l|}{$136-843 \mathrm{~A}-$} \\
\hline 3R- $1,88-90$ & 51.00 & 2.54 & 16.65 & 10.27 & 0.16 & 6.07 & 9.23 & 2.85 & 0.91 & 0.28 & 99.96 & 2.03 \\
\hline $3 R-2,10-12$ & 49.63 & 2.34 & 15.17 & 11.72 & 0.26 & 6.29 & 11.12 & 2.29 & 0.47 & 0.25 & 99.54 & 0.93 \\
\hline $3 R-2,38-40$ & 50.20 & 2.33 & 15.36 & 10.80 & 0.23 & 6.42 & 11.12 & 2.34 & 0.57 & 0.25 & 99.62 & 1.08 \\
\hline \multicolumn{13}{|l|}{$136-843 B-$} \\
\hline $1 \mathrm{R}-1,15-17^{\mathrm{a}}$ & 51.15 & 1.83 & 14.85 & 11.14 & 0.18 & 6.65 & 11.71 & 2.71 & 0.16 & 0.17 & 100.55 & 2.55 \\
\hline $1 R-1,61-63$ & 50.50 & 1.91 & 14.57 & 11.53 & 0.18 & 7.27 & 11.55 & 2.36 & 0.05 & 0.18 & 100.10 & 0.40 \\
\hline $1 R-2,120-122$ & 51.81 & 2.01 & 15.61 & 8.57 & 0.18 & 7.24 & 11.93 & 2.49 & 0.14 & 0.18 & 100.16 & 0.57 \\
\hline $1 \mathrm{R}-3,80-82$ & 49.54 & 1.78 & 13.66 & 14.33 & 0.23 & 6.19 & 10.93 & 2.10 & 0.72 & 0.16 & 99.64 & 0.66 \\
\hline $1 R-4,49-51$ & 50.27 & 1.83 & 13.94 & 13.95 & 0.20 & 5.62 & 10.30 & 2.22 & 0.88 & 0.17 & 99.38 & 0.76 \\
\hline IR-6, 86-88 & 51.29 & 2.00 & 15.23 & 9.68 & 0.18 & 6.85 & 11.42 & 2.57 & 0.33 & 0.19 & 99.74 & 0.46 \\
\hline 1R-6, 105-107 & 50.93 & 2.03 & 15.35 & 9.65 & 0.20 & 7.25 & 11.25 & 2.60 & 0.16 & 0.18 & 99.60 & 0.63 \\
\hline $1 \mathrm{R}-6,132-134$ & 51.12 & 2.00 & 15.38 & 9.96 & 0.18 & 6.75 & 11.35 & 2.55 & 0.36 & 0.22 & 99.87 & 0.67 \\
\hline 2R-1, 107-109 & 50.84 & 2.03 & 15.89 & 9.61 & 0.20 & 6.49 & 10.79 & 2.61 & 0.25 & 0.21 & 98.90 & 2.01 \\
\hline 2R-2, 77-79 & 51.24 & 2.05 & 15.60 & 10.84 & 0.20 & 5.72 & 10.32 & 2.67 & 0.44 & 0.40 & 99.47 & 2.96 \\
\hline $4 \mathrm{R}-1,88-90$ & 50.83 & 2.00 & 15.20 & 10.25 & 0.22 & 6.44 & 11.41 & 2.32 & 0.15 & 0.19 & 99.00 & 2.43 \\
\hline $4 R-2,26-28$ & 51.56 & 2.10 & 15.19 & 9.30 & 0.21 & 6.52 & 11.57 & 2.29 & 0.24 & 0.18 & 99.17 & 1.40 \\
\hline $4 \mathrm{R}-2,80-81^{\mathrm{a}}$ & 51.01 & 2.00 & 15.19 & 10.61 & 0.20 & 6.63 & 11.33 & 2.65 & 0.27 & 0.18 & 100.05 & 2.00 \\
\hline $4 \mathrm{R}-2,92-94^{\mathrm{a}}$ & 49.98 & 1.95 & 14.82 & 13.91 & 0.21 & 5.54 & 10.52 & 2.51 & 0.61 & 0.12 & 100.17 & 1.94 \\
\hline 4R-3, 29-31 & 50.74 & 2.05 & 15.30 & 9.81 & 0.21 & 6.71 & 11.18 & 2.43 & 0.28 & 0.19 & 98.89 & 1.91 \\
\hline
\end{tabular}

Notes: All concentrations in wt\%. LOI = loss on ignition. Analyses performed on board JOIDES Resolution except as noted.

a Analysis performed at University of Hawaii.

used for trace element analysis, and each sample was repeatedly ultrasonically rinsed in deionized water until the decanted liquid was clear. The sample was then washed in dilute $\mathrm{HF}-\mathrm{HNO}_{3}$ for 5-10 min, rinsed and dried. The rock was broken into $\approx 2$-mm-size pieces in a steel mortar, and the residual powder was separated and not analyzed. Under clean-laboratory conditions the sample chips were further cleaned, rinsed, and dried, and then powdered in a clean boron carbide mortar. An acid leaching procedure that leaves a clinopyroxene- and plagioclase-rich residue (see Mahoney, 1987) was used on some sample splits (labeled "L" in Table 4) to eliminate alteration phases. This was done to attempt to determine the original isotopic ratios of the lavas. Digestion with $\mathrm{HF}-\mathrm{HNO}_{3}$, spiking, chemical separation, and mass spectrometric analysis for $\mathrm{Pb}, \mathrm{Sr}$, and $\mathrm{Nd}$ ratios and trace element abundances were performed using procedures described by Mahoney et al. (1991).

Oxygen isotopes (Table 4) were measured at the University of Minnesota on 7 to $15 \mathrm{mg}$ of dried whole-rock powder from each of four samples prepared for radiogenic isotope analyses. Oxygen was extracted using $\mathrm{ClF}_{3}$ (Borthwick and Harmon, 1982) in a procedure similar to the $\mathrm{BrF}_{5}$ method of Clayton and Mayeda (1963). Analysis of the resulting $\mathrm{CO}_{2}$ gas was performed with a Finnigan MAT Delta E triple collector, $90^{\circ}$ sector mass spectrometer.

\section{RESULTS AND INTERPRETATION}

\section{Petrography}

Details of the petrography of the basalt from Site 843 are given in the site chapter and core description forms of the Initial Reports volume (Shipboard Scientific Party, 1992b). Only a brief summary is presented here.

The basalts recovered from Holes $843 \mathrm{~A}$ and $843 \mathrm{~B}$ are nearly aphyric and exhibit low vesicularity $(<1 \mathrm{vol} \%$, increasing locally to $3 \mathrm{vol} \%$ near the glassy pillow margins). Vesicles are small $(<1 \mathrm{~mm})$, round, and commonly filled with clay and/or, rarely, calcite.

The modes of representative basalt samples are presented in Table 5 . The lavas contain rare plagioclase phenocrysts $(<0.1 \mathrm{vol} \%)$ in a partially glassy to holocrystalline matrix of plagioclase, clinopyroxene, minor iron oxides, and rare, altered olivine. Some plagioclase phenocryst cores are altered to sericite (?), but the rims appear unaltered. Groundmass plagioclase compositions, determined by the Michel-Levy technique, are $60 \%$ to $70 \%$ anorthite. Electron microprobe analysis of several plagioclase grains in Sample 136-843B-1R$3,27-28 \mathrm{~cm}$, yields anorthite contents of $60 \% \pm 1 \%$.

The core from Hole 843B was subdivided into four macroscopically similar units (Shipboard Scientific Party, 1992b). Unit 1 is medium gray with a consistent holocrystalline texture. Unit 2 is darker gray and finer grained. Unit 3 contains rare, small gabbroic xenoliths and is otherwise similar to Unit 2. Unit 4 is identical to Unit 3 but is separated from it by a glassy margin. There are large gaps between the cored sections, so there may be more than four flow units within the 70-m drilled section.

The basalts are fractured and locally brecciated. Fractures range in width from hairline to $5 \mathrm{~cm}$ and are filled with clays, Fe-oxyhydroxides, calcite, and, less commonly, pyrite. Brown zones $1-3 \mathrm{~cm}$ wide and dark gray to black halos $1 \mathrm{~mm}$ to $3 \mathrm{~cm}$ wide around the

Table 2. Trace element abundances in Site 843 basalts determined by XRF.

\begin{tabular}{lrrrrrrrrrrr}
\hline $\begin{array}{l}\text { Core, section, } \\
\text { interval (cm) }\end{array}$ & $\mathrm{Sc}$ & $\mathrm{V}$ & $\mathrm{Cr}$ & $\mathrm{Co}$ & $\mathrm{Ni}$ & $\mathrm{Cu}$ & $\mathrm{Zn}$ & $\mathrm{Sr}$ & $\mathrm{Y}$ & $\mathrm{Zr}$ & $\mathrm{Nb}$ \\
\hline 136-843A- & & & & & & & & & & & \\
3R-2, 10-12 & 49 & 462 & 215 & 38 & 55 & 37 & 115 & 153 & 36.6 & 166 & 11.6 \\
3R-2,38-40 & 47 & 393 & 211 & 30 & 54 & 46 & 102 & 149 & 36.6 & 162 & 11.1 \\
136-843B- & & & & & & & & & & & \\
IR-1, 61-63 & 45 & 399 & 143 & 40 & 53 & 79 & 92 & 132 & 33.0 & 124 & 5.8 \\
IR-2,120-122 & 52 & 448 & 147 & 47 & 64 & 67 & 99 & 134 & 27.5 & 131 & 5.7 \\
IR-4, 49-51 & 34 & 398 & 99 & 27 & 38 & 64 & 78 & 124 & 25.3 & 120 & 5.8 \\
IR-6,132-134 & 52 & 351 & 149 & 35 & 57 & 68 & 96 & 136 & 36.3 & 130 & 6.5 \\
2R-1,107-109 & 49 & 420 & 148 & 37 & 53 & 31 & 111 & 126 & 31.0 & 126 & 5.8 \\
2R-2,77-79 & 45 & 304 & 129 & 28 & 39 & 29 & 106 & 133 & 30.0 & 182 & 8.2 \\
4R-2, 80-81 & 51 & 421 & 151 & 39 & 44 & 50 & 106 & 122 & 35.8 & 123 & 6.3 \\
4R-3,29-31 & 51 & 416 & 148 & 43 & 48 & 54 & 105 & 121 & 32.2 & 121 & 6.0 \\
\hline
\end{tabular}

Notes: All concentrations in ppm. Analyses performed at the University of Hawaii. 
Table 3. Trace element abundances in Site 843 basalts determined by ICP-MS.

\begin{tabular}{|c|c|c|c|c|c|c|c|c|c|c|c|c|c|c|c|c|c|c|c|c|c|}
\hline $\begin{array}{l}\text { Core, section, } \\
\text { interval }(\mathrm{cm})\end{array}$ & $\mathrm{Rb}$ & Cs & $\mathrm{Ba}$ & $\mathrm{Hf}$ & $\mathrm{Ta}$ & Th & $\mathrm{U}$ & La & $\mathrm{Ce}$ & $\operatorname{Pr}$ & $\mathrm{Nd}$ & Sm & Eu & Gd & $\mathrm{Tb}$ & Dy & Ho & $\mathrm{Er}$ & $\mathrm{Tm}$ & $\mathrm{Yb}$ & Lu \\
\hline \multicolumn{22}{|l|}{$136-843 \mathrm{~A}-$} \\
\hline $3 R-2,10-12$ & 1.46 & 0.04 & 35 & 3.52 & 0.64 & 0.36 & 0.22 & 4.66 & 11.80 & 2.03 & 10.06 & 3.43 & 1.54 & 4.72 & 0.86 & 5.87 & 1.25 & 3.56 & 0.55 & 3.41 & 0.52 \\
\hline $3 R-2,38-40$ & 10.27 & 0.31 & 33 & 4.09 & 0.67 & 0.56 & 0.31 & 5.47 & 13.63 & 2.23 & 11.19 & 3.79 & 1.52 & 4.87 & 0.90 & 6.09 & 1.30 & 3.86 & 0.59 & 3.70 & 0.55 \\
\hline \multicolumn{22}{|l|}{ 136-843B- } \\
\hline IR-1, 61-63 & 0.17 & 0.01 & 15 & 2.13 & 0.19 & 0.16 & 0.07 & 2.28 & 6.35 & 1.16 & 6.05 & 2.35 & 1.25 & 3.35 & 0.63 & 4.43 & 0.97 & 2.89 & 0.46 & 2.84 & 0.43 \\
\hline $1 \mathrm{R}-2,120-122$ & 0.96 & 0.02 & 16 & 2.74 & 0.10 & 0.18 & 0.03 & 1.97 & 5.62 & 1.08 & 5.60 & 2.28 & 1.22 & 3.26 & 0.64 & 4.50 & 0.96 & 2.89 & 0.47 & 3.04 & 0.47 \\
\hline $1 R-4,49-51$ & 19.80 & 0.32 & 23 & 2.96 & 0.27 & 0.28 & 0.13 & 2.18 & 5.77 & 1.02 & 5.47 & 2.07 & 1.17 & 2.95 & 0.58 & 4.11 & 0.91 & 2.76 & 0.45 & 2.89 & 0.44 \\
\hline $2 \mathrm{R}-2,77-79$ & 14.86 & 0.40 & 21 & 4.56 & 0.42 & 0.25 & 0.46 & 2.60 & 7.37 & 1.28 & 6.84 & 2.61 & 1.34 & 3.60 & 0.68 & 4.79 & 1.04 & 3.08 & 0.48 & 3.03 & 0.45 \\
\hline 4R-3, 29-31 & 11.24 & 0.33 & 18 & 3.36 & 0.31 & 0.34 & 0.10 & 3.28 & 9.70 & 1.70 & 9.22 & 3.31 & 1.40 & 4.48 & 0.81 & 5.62 & 1.22 & 3.65 & 0.58 & 3.64 & 0.54 \\
\hline BHVO-1 Standard (Average) & 9.09 & 0.10 & 132 & 4.04 & 1.23 & 1.23 & 0.43 & 15.17 & 37.80 & 5.48 & 24.29 & 6.01 & 2.06 & 6.07 & 0.91 & 5.26 & 0.96 & 2.48 & 0.35 & 1.97 & 0.27 \\
\hline BHVO-1 Standard (Consensus) & 9.35 & 0.13 & 132 & 4.39 & 1.23 & 1.10 & 0.42 & 15.39 & 38.09 & 5.80 & 24.70 & 6.13 & 2.09 & 6.31 & 0.88 & 5.33 & 1.02 & 2.56 & 0.33 & 2.01 & 0.28 \\
\hline
\end{tabular}

Notes: All concentrations in ppm. Analyses performed at Washington State University, BHVO-1 consensus values from Gladney and Roelandts (1988), Govindaraju (1989), and A. Hofmann (pers. comm., 1991).

Table 4. $\mathrm{Sr}, \mathrm{Nd}, \mathrm{Pb}$, and $\mathrm{O}$ isotope ratios and isotope dilution-determined trace element concentrations in Site 843 basalts.

\begin{tabular}{|c|c|c|c|c|c|c|c|c|c|c|c|c|c|c|}
\hline $\begin{array}{l}\text { Core, section, } \\
\text { interval }(\mathrm{cm})\end{array}$ & $\mathrm{Rb}$ & $\mathrm{Sr}$ & $\mathrm{Nd}$ & $\mathrm{Sm}$ & $\mathrm{Pb}$ & $\delta^{18} \mathrm{O}$ & ${ }^{87} \mathrm{Sr} /{ }^{86} \mathrm{Sr}$ & ${ }^{87} \mathrm{Sr} /{ }^{86} \mathrm{Sr}_{\mathrm{i}}$ & ${ }^{87} \mathrm{Rb} /{ }^{86} \mathrm{Sr}$ & ${ }^{143} \mathrm{Nd} /{ }^{144} \mathrm{Nd}$ & ${ }^{143} \mathrm{Nd} /{ }^{144} \mathrm{Nd}_{\mathrm{i}}$ & ${ }^{147} \mathrm{Sm} /{ }^{144} \mathrm{Nd}$ & $\varepsilon_{\mathrm{Nd}}$ & $\varepsilon_{\mathrm{Ndi}}$ \\
\hline \multicolumn{15}{|l|}{$136-843 \mathrm{~A}-$} \\
\hline $3 R-2,10-12$ & 1.06 & 143.8 & 10.93 & 3.653 & 0.491 & $+7.9,+8.2$ & 0.70281 & 0.70278 & 0.0213 & 0.513076 & 0.51293 & 0.2020 & +8.5 & +8.4 \\
\hline $3 \mathrm{R}-2,10-12, \mathrm{~L}$ & 0.62 & 175.4 & & & & & 0.70264 & 0.70263 & 0.0102 & & & & & \\
\hline $3 R-2,38-40$ & 14.0 & 146.6 & 6.692 & 2.527 & 0.491 & & 0.70305 & 0.70262 & 0.2756 & 0.513140 & 0.51298 & 0.2282 & +9.7 & +9.3 \\
\hline \multicolumn{15}{|l|}{$136-843 \mathrm{~B}-$} \\
\hline IR-1, 15-17 & 1.11 & 135.4 & 9.913 & 3.429 & 0.133 & & 0.70271 & 0.70268 & 0.0236 & 0.513083 & 0.51293 & 0.2091 & +8.6 & +8.4 \\
\hline $1 \mathrm{R}-1,15-17, \mathrm{~L}$ & 0.07 & 102.1 & 2.572 & 1.297 & 0.0422 & & 0.70267 & 0.70266 & 0.0020 & 0.513178 & 0.51296 & 0.3049 & +10.5 & +9.0 \\
\hline $1 \mathrm{R}-1,61-63$ & 0.12 & 129.9 & 4.826 & 2.007 & 0.203 & +6.4 & 0.70271 & 0.70270 & 0.0027 & 0.513167 & 0.51299 & 0.2514 & +10.3 & +9.6 \\
\hline $1 \mathrm{R}-1,61-63, \mathrm{~L}$ & 0.06 & 122.4 & & & & & 0.70265 & 0.70264 & 0.0014 & & & & & \\
\hline $2 \mathrm{R}-2,77-79$ & 18.6 & 125.2 & 11.14 & 3.732 & 0.856 & +8.7 & 0.70367 & 0.70300 & 0.4285 & 0.513114 & 0.51297 & 0.2024 & +9.2 & +9.2 \\
\hline $2 \mathrm{R}-2,77-79, \mathrm{~L}$ & 0.37 & 141.8 & 4.742 & 2.257 & 0.0729 & & 0.70273 & 0.70272 & 0.0076 & 0.513156 & 0.51295 & 0.2877 & +10.1 & +8.8 \\
\hline $4 \mathrm{R}-3,29-31$ & 11.4 & 113.8 & 8.450 & 3.021 & 0.351 & +7.9 & 0.70344 & 0.70299 & 0.2889 & 0.513112 & 0.51296 & 0.2161 & +9.2 & +9.0 \\
\hline $4 \mathrm{R}-3,29-31, \mathrm{~L}$ & 1.89 & 126.4 & 4.696 & 2.114 & & & 0.70282 & 0.70275 & 0.0433 & 0.513162 & 0.51297 & 0.2722 & +10.2 & +9.2 \\
\hline
\end{tabular}

\begin{tabular}{ccccccc}
\hline $\begin{array}{c}\text { Core, section, } \\
\text { interval }(\mathrm{cm})\end{array}$ & ${ }^{206} \mathrm{~Pb} /{ }^{204} \mathrm{~Pb}$ & ${ }^{207} \mathrm{~Pb} /{ }^{204} \mathrm{~Pb}$ & ${ }^{208} \mathrm{~Pb} /{ }^{204} \mathrm{~Pb}$ & ${ }^{206} \mathrm{~Pb} /{ }^{204} \mathrm{~Pb}_{\mathrm{i}}$ & ${ }^{207} \mathrm{~Pb} /{ }^{204} \mathrm{~Pb}_{\mathrm{i}}$ & ${ }^{208} \mathrm{~Pb} /{ }^{204} \mathrm{~Pb}_{\mathrm{i}}$ \\
\hline $\begin{array}{l}\text { 136-843A- } \\
\text { 3R-2, 10-12 }\end{array}$ & 18.521 & 15.534 & 38.138 & 18.033 & 15.510 & 37.876 \\
3R-2,38-40 & 18.546 & 15.562 & 38.265 & 17.923 & 15.532 & 37.901 \\
136-843B- & & & & & & \\
1R-1, 15-17 & 18.658 & 15.545 & 38.288 & 17.918 & 15.509 & 37.722 \\
1R-1,15-17, L & 18.239 & 15.492 & 37.814 & & & \\
1R-1,61-63 & 18.469 & 15.519 & 38.067 & 18.095 & 15.501 & 37.787 \\
2R-2,77-79 & 18.820 & 15.508 & 37.917 & 18.235 & 15.480 & 37.813 \\
4R-3,29-31 & 18.531 & 15.520 & 38.176 & 18.220 & 15.505 & 37.830 \\
\hline
\end{tabular}

Notes: Trace element concentrations in ppm. $\mathrm{L}=$ leached sample split. $\mathrm{i}=$ initial isotopic ratio at $110 \mathrm{Ma}$.

$\mathrm{O}$ analyses performed at the University of Minnesota. All other analyses performed at the University of Hawaii (UH).

$\mathrm{O}$ isotope ratios are normalized to SLAP $\left(\delta^{18} \mathrm{OV}\right.$.SMOW $\left.=-55.0 \% \mathrm{c}\right)$ and reported relative to V.SMOW. The $\delta^{18} \mathrm{O}$ value for NBS-28 quartz on this scale is $+9.5 \pm 0.15 \%$.

Isotopic fractionation correction for $\mathrm{Nd}$ is ${ }^{148} \mathrm{NdO} /{ }^{144} \mathrm{NdO}=0.242436\left({ }^{148} \mathrm{Nd} / /^{144} \mathrm{Nd}=0.241572\right)$; for $\mathrm{Sr}$ it is ${ }^{86} \mathrm{Sr} /{ }^{88} \mathrm{Sr}=0.1194$.

$\mathrm{Pb}$ values are adjusted relative to the NBS 981 values of Todt et al. (1984).

$\mathrm{Nd}$ isotopic data are reported relative to UH measured ${ }^{143} \mathrm{Nd} /{ }^{144} \mathrm{Nd}$ values for the La Jolla Nd standard of $0.511855 \pm 0.000012$ total range.

$\mathrm{Sr}$ isotopic data are reported relative to UH measured ${ }^{87} \mathrm{Sr} /{ }^{86} \mathrm{Sr}$ values for NBS 987 of $0.71025 \pm 0.00002$ total range.

Within-run uncertainties on sample Nd and $\mathrm{Sr}$ isotopic ratios are less than total ranges measured on La Jolla Nd and NBS 987 standards.

Estimated uncertainty on ${ }^{206 \mathrm{~Pb}} / 204 \mathrm{~Pb}$ is \pm 0.010 ; on ${ }^{207} \mathrm{~Pb} / 204 \mathrm{~Pb}$ it is \pm 0.009 ; and on ${ }^{208} \mathrm{~Pb} / 204 \mathrm{~Pb}$ it is \pm 0.032 ; based on total ranges measured for $\mathrm{NBS} 981$.

Total blanks are: $\mathrm{Pb}=5-40 \mathrm{pg}, \mathrm{Nd} \leq 20 \mathrm{pg}$, and $\mathrm{Sr} \leq 120 \mathrm{pg}$.

fractures and veins are probably due to low-temperature seawater alteration (Alt, this volume). Portions of the rock farther from the fractures are lighter gray and appear less altered.

\section{Major And Trace Elements}

The lavas are quartz-normative tholeiites (assuming $\mathrm{FeO}=0.9$ $\times \mathrm{FeO}^{*}$, where $\mathrm{FeO}^{*}$ is total iron as $\mathrm{FeO}$ ), with a normative plagioclase anorthite content ranging from $55 \%$ to $61 \%$ (average $59 \%$ ). The $\mathrm{Mg}$ number $\left(100 \times \mathrm{Mg} /\left(\mathrm{Mg}+\mathrm{Fe}^{2+}\right)\right.$, assuming $\left.\mathrm{FeO}=0.9 \times \mathrm{FeO}^{*}\right)$ of the Site 843 lavas varies from 47 to 65 (average 57), which is typical of moderately fractionated, Pacific MORB (Wilson, 1989).

Because of the essentially aphyric nature of the Site 843 basalts, the whole-rock XRF analyses (Table 1) should be representative of the original magmatic major element composition of the lavas, if the composition has not been modified by low-temperature alteration. Such alteration would tend to increase $\mathrm{K}_{2} \mathrm{O}$ content and loss on ignition (LOI), and produce a good correlation between $\mathrm{K}_{2} \mathrm{O}$ and LOI (e.g., Honnorez, 1981; Thompson, 1983) if the basalts crystallized from low- $\mathrm{K}_{2} \mathrm{O}$, anhydrous melts. The three samples from Hole $843 \mathrm{~A}$ are nearly colinear, but no such correlation is observed in the 15 samples from Hole 843B (Fig. 3), or in those studied by Alt (this volume). However, samples with LOI $>1.1 \mathrm{wt} \%$ must have experienced some alteration. The greatest LOI is found in the finer-grained rocks from the upper part of both holes and from the lower part of Hole 843B (Table 1 and Fig. 2). The higher LOI in these parts of the cores is probably due to the filling of vesicles and replacement of olivine and matrix glass by clays. Rocks from these areas were included in the suite of samples analyzed for trace elements to evaluate the present compositional range of the Site 843 lavas. 
Table 5. Modes of primary minerals in basalts from Site 843.

\begin{tabular}{|c|c|c|c|c|c|c|c|c|c|c|c|c|c|c|c|c|}
\hline \multicolumn{17}{|l|}{ Sample } \\
\hline Hole & $843 \mathrm{~A}$ & $843 \mathrm{~A}$ & $843 \mathrm{~A}$ & $843 \mathrm{~A}$ & $843 B$ & $843 B$ & $843 B$ & $843 B$ & $843 B$ & $843 B$ & $843 B$ & $843 B$ & 843B & $843 B$ & 843B & $843 B$ \\
\hline \multirow{2}{*}{$\begin{array}{l}\text { Core, section, } \\
\text { interval }(\mathrm{cm})\end{array}$} & $3 R-1$ & $3 \mathrm{R}-2$ & $3 \mathrm{R}-2$ & $1 \mathrm{R}-1$ & IR-1 & 1R-2 & 1R-3 & 1R-6 & IR-6 & $2 \mathrm{R}-1$ & $2 \mathrm{R}-2$ & $4 \mathrm{R}-1$ & $4 \mathrm{R}-2$ & $4 \mathrm{R}-2$ & $4 \mathrm{R}-3$ & $3 \mathrm{R}-1$ \\
\hline & $83-85$ & $93-94$ & $5-6$ & $26-28$ & $7-8$ & $72-74$ & $35-37$ & $83-85$ & $93-95$ & $102-104$ & $106-108$ & $16-18$ & $40-42$ & 7.9 & $89-91$ & $30-32$ \\
\hline \multicolumn{17}{|l|}{ Phenocrysts } \\
\hline Plagioclase & 0.1 & 0.1 & 0.1 & 0.1 & - & $<0.1$ & 0.1 & - & $<0.1$ & $<0.1$ & $<0.1$ & $<0.1$ & - & $<0.1$ & $<0.1$ & $<0.1$ \\
\hline Clinopyroxene & - & - & - & - & - & - & - & - & - & - & - & - & - & - & - & - \\
\hline \multirow{2}{*}{\multicolumn{17}{|c|}{ Groundmass }} \\
\hline & & & & & & & & & & & & & & & & \\
\hline Plagioclase & 17 & 31 & 36 & 39 & 45 & 45 & 10 & 39 & 4 & 16 & 40 & 5 & 40 & 41 & 15 & 21 \\
\hline Clinopyroxene & 9 & 17 & 22 & 26 & 18 & 28 & 7 & 21 & 4 & 9 & 20 & 0 & 25 & 25 & 9 & 12 \\
\hline Olivine & 5 & 11 & 16 & 22 & 16 & 10 & 5 & 19 & 1 & 4 & 11 & 0 & 10 & 16 & 6 & 6 \\
\hline Fe-Oxides & 4 & 15 & 11 & 11 & 12 & 10 & 9 & 8 & 12 & 13 & 13 & 0 & 12 & 9 & 11 & 12 \\
\hline Glass $^{\mathrm{a}}$ & 65 & 26 & 15 & 2 & 9 & 7 & 61 & 12 & 79 & 58 & 16 & 95 & 13 & 9 & 59 & 49 \\
\hline Vesicularity & 3 & 3 & 1 & $<1$ & 1 & 1 & $<1$ & $<0.1$ & 3 & $<1$ & 1 & $<0.1$ & $<0.1$ & 1 & 1 & $<1$ \\
\hline
\end{tabular}

Notes: All values in vol\%. Modes based on 500 points per sample. Analyst: G. Waggoner.

a Includes very fine-grained material.

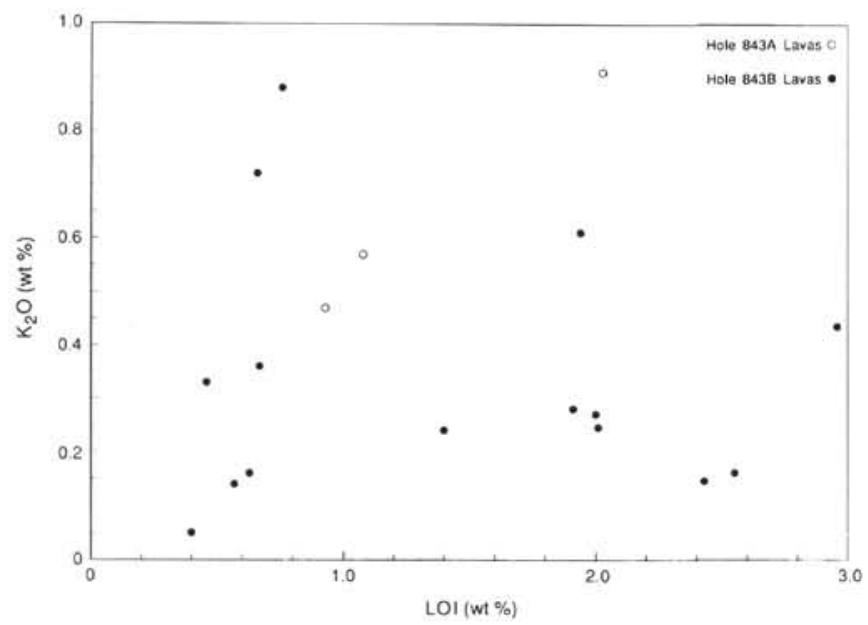

Figure 3. Plot of $\mathrm{K}_{2} \mathrm{O}$ vs. LOI. LOI = loss on ignition. Note lack of correlation for Hole 843B lavas.

Within this group of petrographically similar lavas, there is a substantial range in composition (e.g., $\mathrm{MgO}, 5.5$ to $7.3 \mathrm{wt} \%$; $\mathrm{TiO}_{2}$, 1.8 to $2.5 \mathrm{wt} \%$ ). However, this compositional variation does not produce systematic trends on $\mathrm{MgO}$ variation diagrams except for $\mathrm{CaO}$ and $\mathrm{K}_{2} \mathrm{O}$ (Fig. 4). Lavas from Holes $843 \mathrm{~A}$ and $843 \mathrm{~B}$ differ from each other in major element compositions, especially in $\mathrm{TiO}_{2}$ (Fig. 4), which is resistant to alteration.

Many of the Site 843 lavas are enriched in $\mathrm{K}_{2} \mathrm{O}$ relative to normal MORB (N-MORB) from $13^{\circ}$ to $23^{\circ} \mathrm{S}$ on the EPR at the same $\mathrm{MgO}$ (Sinton et al., 1991; Fig. 4), and thus may be considered transitional MORB (T-MORB), according to the terminology of Bass (1972). Sinton et al. (1991) characterized T-MORB as having, in addition to $\mathrm{K}_{2} \mathrm{O}$ enrichment, higher $\mathrm{K} / \mathrm{Ti}$ and $\mathrm{K} / \mathrm{P}$ ratios than associated $\mathrm{N}$ MORB. The Site 843 basalts have a $\mathrm{K} / \mathrm{Ti}$ range of $0.04-0.67$ (average 0.26 ), and a $\mathrm{K} / \mathrm{P}$ range of $0.53-9.85$ (average 3.78 ). These values are, for the most part, considerably higher than those for N-MORB from $13^{\circ}$ to $23^{\circ} \mathrm{S}$ on the EPR, which have a $\mathrm{K} / \mathrm{Ti}$ range of about $0.03-0.1$ and a K/P range of about $0.4-1.6$ at the same $\mathrm{MgO}$ (Sinton et al., 1991). Although $\mathrm{K}_{2} \mathrm{O}$ content in the Site 843 basalts may have been affected by seawater alteration, their T-MORB nature is indicated by their trace element composition. A plot of $\mathrm{Y} / \mathrm{Nb}$ vs. $\mathrm{Zr} / \mathrm{Nb}$ (Fig. 5) illustrates the similarity of the Site 843 basalts to T-MORB from $13^{\circ}$ to $23^{\circ} \mathrm{S}$ on the EPR and compares the lavas with N-MORB and some EPR seamounts from the same location. In addition to $\mathrm{K}_{2} \mathrm{O}$ enrichment, T-MORB from $13^{\circ}$ to $23^{\circ} \mathrm{S}$ on the EPR are commonly enriched in $\mathrm{Nb}, \mathrm{Th}, \mathrm{Ba}, \mathrm{Rb}, \mathrm{Ta}$, and light REE relative to $\mathrm{N}-\mathrm{MORB}$ from the same location (Sinton and Niu, 1991; J. Sinton, pers. comm., 1993).

The four macroscopically similar rock units described on board JOIDES Resolution for basalt cores from Hole 843B are not chemi- cally distinct. There are variations in major and trace element compositions both within and between the four units. The basalt cores recovered at Site 843 could be divided geochemically into several units based on major element composition (Table 1), but only two rock units are indicated by trace element compositions (Tables 2 and 3): Hole $843 \mathrm{~A}$ and Hole $843 \mathrm{~B}$ lavas.

Hole 843A lavas are enriched in Ti, K, P, Cr, Sr, Y, Zr, Nb, Ba, Ta, and the light and middle REE relative to Hole $843 \mathrm{~B}$ lavas, with the exception of Sample 136-843B-2R-2, 77-79 cm. Various ratios of alteration-resistant incompatible elements (e.g., $\mathrm{Zr} / \mathrm{Nb}, \mathrm{Hf} / \mathrm{Ta}, \mathrm{La} / \mathrm{Sm}$, and $\mathrm{La} / \mathrm{Yb}$ ) also show Hole $843 \mathrm{~A}$ lavas to be distinct from Hole 843B lavas. However, these ratios are nearly constant for lavas within each hole, whereas compatible trace elements (e.g., $\mathrm{Cr}$ and $\mathrm{Ni}$ ) within Hole $843 \mathrm{~B}$ vary substantially $(\mathrm{Cr}, 99$ to $151 \mathrm{ppm})$. These features indicate that the lavas in Hole 843B may have been derived from a common or similar source.

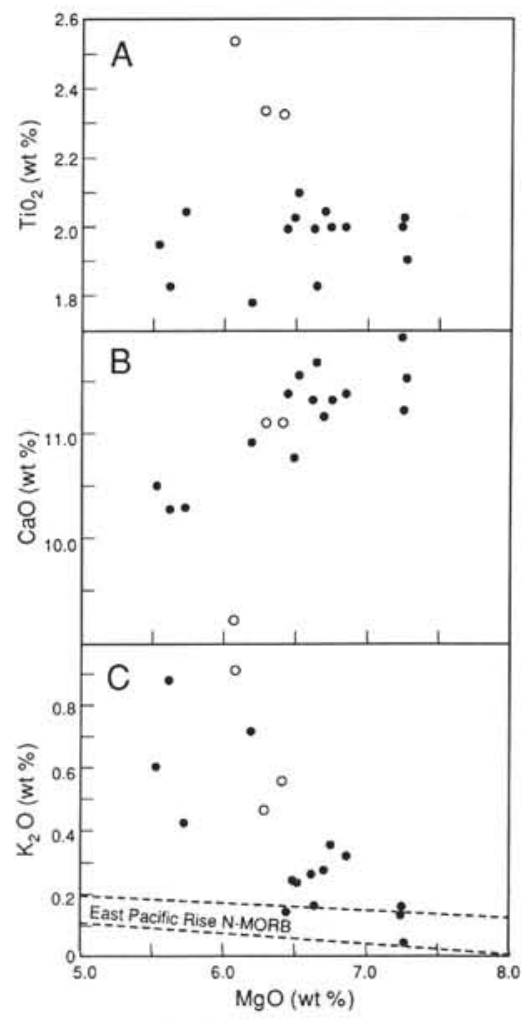

Figure 4. $\mathrm{MgO}$ variation diagrams for $(\mathbf{A}) \mathrm{TiO}_{2},(\mathbf{B}) \mathrm{CaO}$, and (C) $\mathrm{K}_{2} \mathrm{O}$. Note difference in $\mathrm{TiO}_{2}$ for lavas from Holes $843 \mathrm{~A}$ and $843 \mathrm{~B}$. $\mathrm{K}_{2} \mathrm{O}$ field for EPR N-MORB after Sinton et al. (1991). Symbols are the same as in Figure 3. 


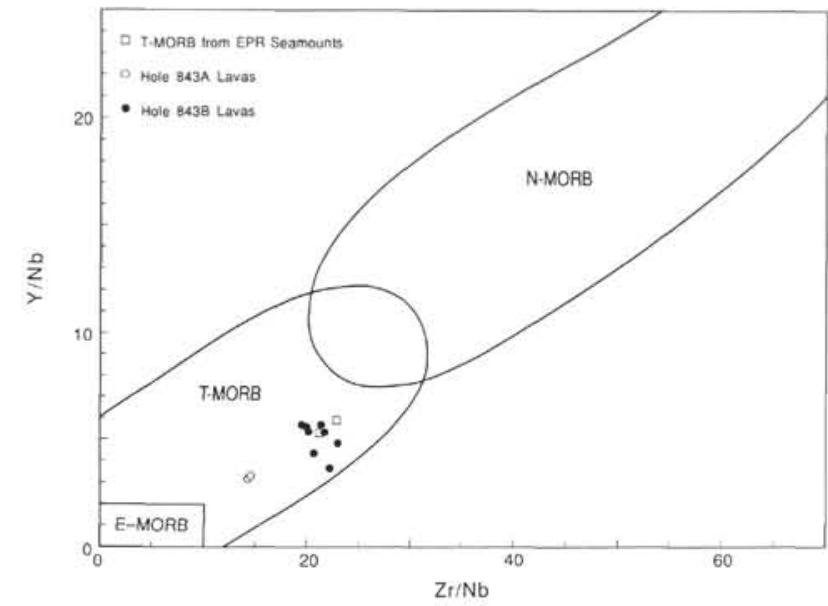

Figure 5. Plot of $\mathrm{Y} / \mathrm{Nb}$ vs. $\mathrm{Zr} / \mathrm{Nb}$, after Wilson (1989). E-MORB = enriched MORB. Fields for N-MORB and T-MORB from EPR axial lavas from $13^{\circ}-$ $23^{\circ} \mathrm{S}$ (Sinton et al., unpubl. data). Data for seamount T-MORB from $18^{\circ}-19^{\circ} \mathrm{S}$ on the EPR from Sinton and Niu (unpubl. data).

Site 843 lavas have chondrite-normalized REE patterns that range from nearly flat (Hole 843A samples) to light-REE depleted (Hole $843 \mathrm{~B}$ samples; Fig. 6). (La/Sm) $)_{N}$ ratios range from $0.5-0.9$, overlapping to slightly higher than the range of $\mathrm{N}-\mathrm{MORB}(0.4-0.7$; Schilling, 1975; Sun et al., 1979) but below that of enriched MORB (E-MORB) (>1; Sun et al., 1979; Wilson, 1989). The overall patterns are smooth except for minor negative $\mathrm{Ce}$ anomalies for some samples and minor to large positive Eu anomalies for all samples (Fig. 6). The negative $\mathrm{Ce}$ anomalies are probably related to low-temperature alteration (e.g., Price et al., 1991). The source of the Eu anomaly is discussed below.

Figure 7A shows the N-MORB normalized patterns for incompatible elements in representative lavas from Site 843. These lavas are enriched in HFSE (Th, $\mathrm{U}, \mathrm{Ta}, \mathrm{Nb}, \mathrm{Zr}, \mathrm{Hf}, \mathrm{Ti}$ ) and $\mathrm{P}, \mathrm{Ba}$, and $\mathrm{K}$ relative to N-MORB. The other elements have N-MORB normalized patterns that range from slightly depleted (REE except Eu) to somewhat enriched (Eu, Sr). The altered Sample 136-843B-2R-2, 77-79 cm (shown by filled-circle symbols in Figure 7), is distinctly different from the other lavas in that it has higher concentrations of $\mathrm{U}, \mathrm{Pb}$, and $\mathrm{P}$. The higher $\mathrm{Pb}$ and $\mathrm{U}$ concentrations are consistent with the enrichment in these elements relative to fresh N-MORB that is observed in

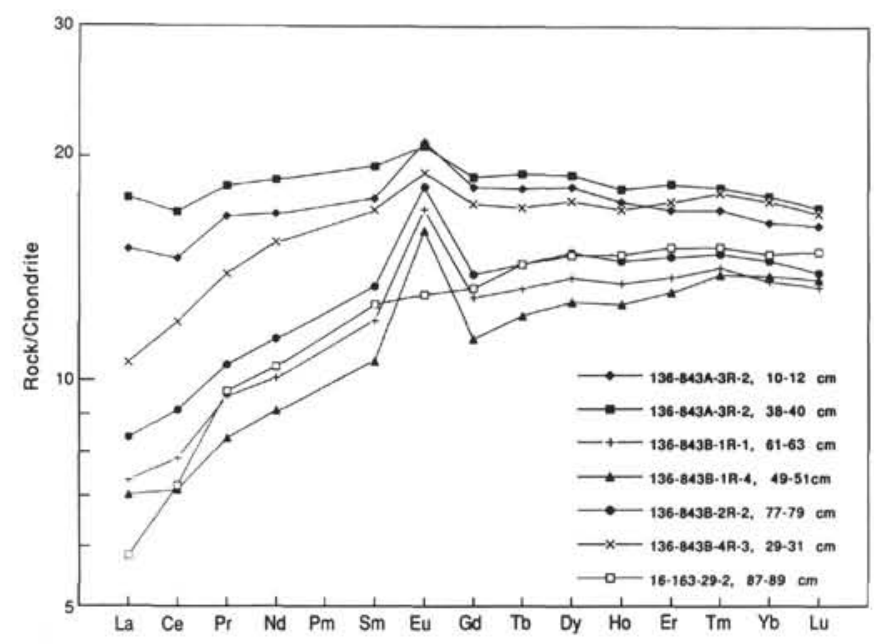

Figure 6. Chondrite-normalized REE diagram. Central Pacific DSDP basalt Sample 16-163-29-2, 87-89 cm, like the Site 843 samples, was analyzed at Washington State University in 1992, and is included in this figure to show that the positive Eu anomaly in the Site 843 lavas is not the result of analytical error. Chondrite normalization values from Boynton (1984).
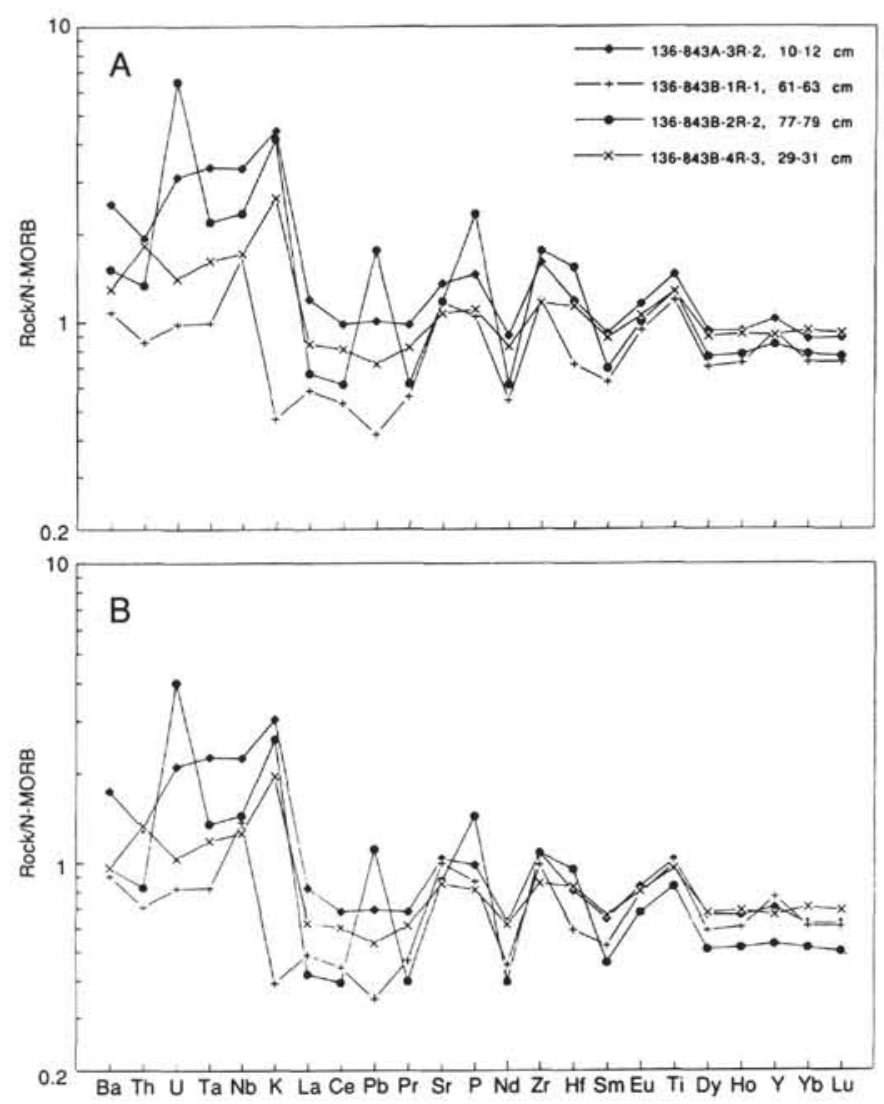

Figure 7. N-MORB normalization diagrams. A. Uncorrected data. Note the difference in the pattern of the highly altered Sample 136-843B-2R-2, 77-79 $\mathrm{cm}$. B. Same samples after correction for fractional crystallization to $\mathrm{MgO}=$ $8.0 \mathrm{wt} \%$. See text for explanation. Note enrichment in $\mathrm{U}, \mathrm{Ta}, \mathrm{Nb}$, and $\mathrm{K}$ and depletion in REE relative to N-MORB and to other elements. N-MORB normalization values from Hofmann (1988).

low-temperature alteration minerals found in oceanic crustal basalts (Hart and Staudigel, 1986).

A few incompatible elements exhibit a wide range in content in the Site 843 lavas (e.g., Cs, Rb, Th, U, and K; Tables 1 and 3), probably due to their susceptibility to mobility during seawater alteration. Although alteration has affected concentrations of these elements in some samples (e.g., 136-843B-2R-2, 77-79 cm), Sr isotopic data and $\mathrm{Rb}-\mathrm{Sr}$ isochron relationships indicate that the high $\mathrm{K}$ and $\mathrm{Rb}$ concentrations in some of the Site 843 basalts (e.g., 136-843B-1R-4, 49-51 $\mathrm{cm}$ ) are those of the unaltered, original rock (Waggoner, this volume).

The Site 843 basalts are distinctly lower in $\mathrm{Ba} / \mathrm{Nb}$ and $\mathrm{La} / \mathrm{Nb}$ ratios ( $\approx 3$ and 0.4 , respectively) than are other oceanic lavas, such as ocean island basalts (OIB), island arc basalts (IAB), HIMU (high ${ }^{238} \mathrm{U}^{204} \mathrm{~Pb}$ ) basalts, and N-MORB, as well as end-member compositions such as primitive mantle and continental lithosphere (Fig. 8). Thus, major element composition and some trace element abundances indicate that the Site 843 lavas have N-MORB to T-MORB affinities, whereas the enrichment in $\mathrm{Eu}$ and HFSE, and the low $\mathrm{Ba} / \mathrm{Nb}$ and $\mathrm{La} / \mathrm{Nb}$ ratios, indicate that these basalts are distinct from most present-day MORB.

\section{Strontium, Neodymium, and Lead Isotopes}

$\mathrm{Sr}, \mathrm{Nd}$, and $\mathrm{Pb}$ isotope ratios and isotope dilution abundance data for $\mathrm{Sr}, \mathrm{Rb}, \mathrm{Sm}, \mathrm{Nd}$, and $\mathrm{Pb}$ were determined for the Site 843 basalts (Table 4). Leached and unleached splits of five lava samples representative of the compositional range at various depths were analyzed for ${ }^{87} \mathrm{Sr} /{ }^{86} \mathrm{Sr}$ and $\mathrm{Rb} / \mathrm{Sr}$ systematics. One of the samples, 136-843B$2 \mathrm{R}-2,77-79 \mathrm{~cm}$, was selected to determine the isotopic ratios of a 


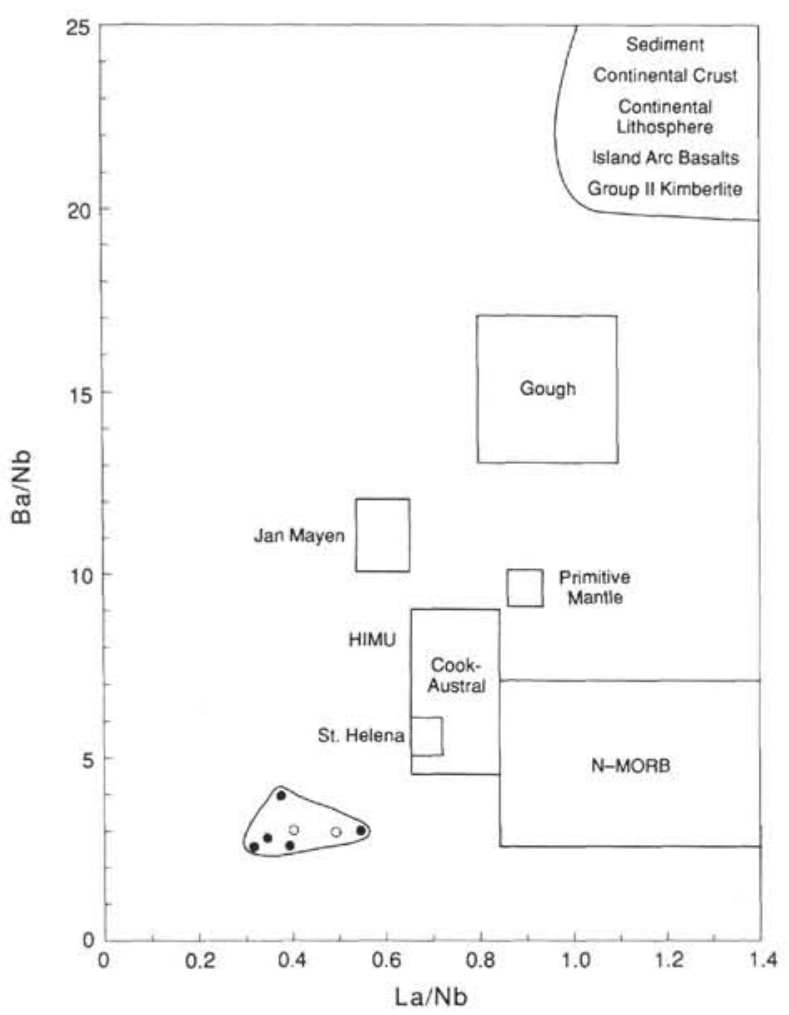

Figure 8. Plot of $\mathrm{Ba} / \mathrm{Nb}$ vs. La/Nb, after Weaver et al. (1986) and Waggoner (1989). Symbols are the same as those in Figure 3.

highly altered, Cretaceous seafloor basalt. In Samples 136-843B-2R$2,77-79 \mathrm{~cm}$, and $136-843 \mathrm{~B}-4 \mathrm{R}-3,29-31 \mathrm{~cm}$, the respective differences in ${ }^{87} \mathrm{Sr} /{ }^{86} \mathrm{Sr}$ between unleached $(0.7037$ and 0.7034$)$ and leached (0.7027 and 0.7028$)$ sample splits are consistent with substantial amounts of seawater alteration. The other three unleached and leached sample splits have $\mathrm{Sr}$ ratios that are typical of the range for fresh, unaltered N-MORB (0.7024 to 0.7030). In each case, the leached split has a slightly lower ${ }^{87} \mathrm{Sr} /{ }^{86} \mathrm{Sr}$ ratio (average 0.00009 lower; Table 4). Sample 136-843B-2R-2, 77-79 cm, is aphyric gray basalt with 25 vol\% veins $\leq 1 \mathrm{~mm}$ wide, which are filled with calcite and green and red clays. Sample 136-843B-4R-3, 29-31 cm, did not outwardly appear altered, but it was reduced considerably in weight by the leaching process, suggesting loss of alteration phases. In thin section, Sample 136-843B-4R-3, 29-31 cm, is seen to contain about $30 \mathrm{vol} \%$ green and red clays in veins and in numerous isolated patches in the groundmass and around microphenocrysts. These two most-altered samples, 136-843B-2R-2, 77-79 cm, and 136-843B-4R-3, 29-31 cm, were analyzed as unleached and leached splits for $\mathrm{Nd}$ isotopes. Sample 136-843B-1R-1, 15-17 cm, was analyzed as unleached and leached splits for $\mathrm{Nd}$ and $\mathrm{Pb}$ isotopes.

The isotopic relations of Site 843 basalts to Southern Hemisphere EPR MORB, Hawaiian shield-building tholeiites, and Hawaiian postshield and post-erosional lavas are shown in Figures 9, 10, and 11. The basalts recovered from Site 843 are isotopically similar to many present-day EPR MORB. Their present-day ${ }^{208} \mathrm{~Pb} /{ }^{204} \mathrm{~Pb}$ ratios range from 37.9 to $38.3,{ }^{207} \mathrm{~Pb} / 204 \mathrm{~Pb}$ from 15.5 to $15.6,{ }^{206} \mathrm{~Pb} /{ }^{204} \mathrm{~Pb}$ from 18.5 to $18.8,{ }^{87} \mathrm{Sr}{ }^{86} \mathrm{Sr}$ from 0.70271 to 0.70367 , and ${ }^{143} \mathrm{Nd} /{ }^{144} \mathrm{Nd}$ from 0.51308 to $0.51317\left(\varepsilon_{\mathrm{Nd}}\right.$ from +8.6 to +10.3 ). Figures 9 and 10 show two Cretaceous Pacific MORB samples from DSDP Leg 17 for comparison. These two samples are altered crustal lavas that were not acid leached before analysis for $\mathrm{Pb}$ and $\mathrm{Sr}$ isotope ratios, and are age corrected to an assumed age of $95 \mathrm{Ma}$ (see Bass et al., 1973).

Altered Sample 136-843B-2R-2,77-79 cm, has a noticeably higher ${ }^{206} \mathrm{~Pb} /{ }^{204} \mathrm{~Pb}$ ratio than the other samples (Figs. 9 and 10). This is

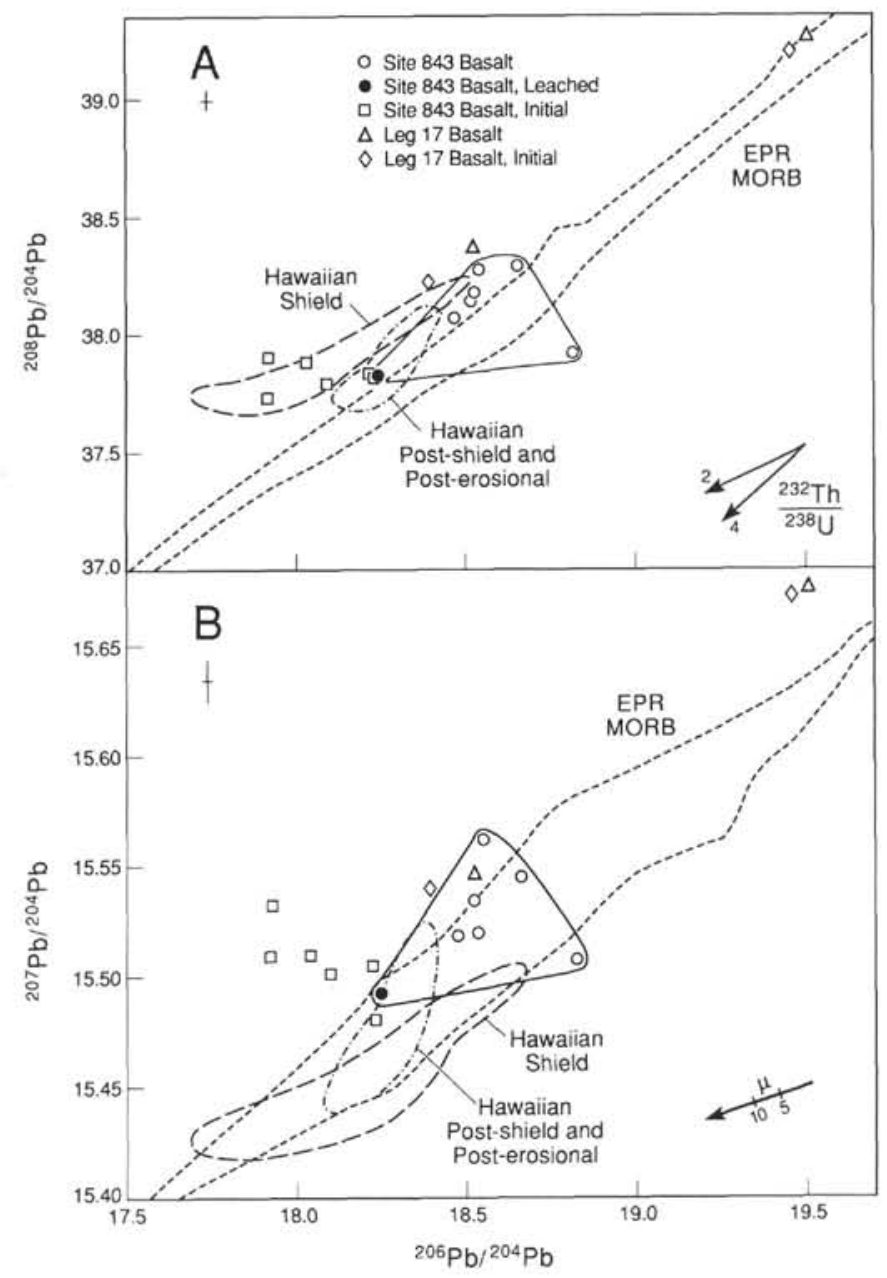

Figure 9. Plots of $\mathrm{Pb}$ isotope ratios in Site 843 basalts. A. ${ }^{208} \mathrm{~Pb} /{ }^{204} \mathrm{~Pb}$ vs. ${ }^{206} \mathrm{~Pb} /$ ${ }^{204} \mathrm{~Pb}$. B. ${ }^{207} \mathrm{~Pb} /{ }^{204} \mathrm{~Pb}$ vs. ${ }^{206} \mathrm{~Pb} /{ }^{204} \mathrm{~Pb}$. Note higher ${ }^{206} \mathrm{~Pb} /{ }^{204} \mathrm{~Pb}$ ratio of the altered Sample 136-843B-2R-2, 77-79 cm, in this figure and in Figure 10, probably due to addition of $\mathrm{U}$ from seawater. Vectors at lower right indicate direction of age correction, where $\mu={ }^{238} \mathrm{U} /{ }^{204} \mathrm{~Pb}$. Error bars in upper left corners are $\pm 2 \sigma$ and apply to all Site 843 basalt isotope ratios except initial $\mathrm{Pb}$ ratios (see text). Two Cretaceous Pacific MORB samples from DSDP Leg 17 are shown for comparison. Data for Leg 17 basalts from Bass et al. (1973). EPR MORB field (including Easter Microplate data) from data of MacDougall and Lugmair (1986), Ito et al. (1987), White et al. (1987), Hanan and Schilling (1989), and Fontignie and Schilling (1991). Fields for Hawaiian lavas from data of West et al. (1987), West and Leeman (1987), West et al. (1992), and Garcia et al. (1993).

probably the result of addition of $U$ during the extensive seawater alteration of this basalt that produced its numerous small veins. Enrichment of $\mathrm{U}$ relative to $\mathrm{Pb}$ and Th during alteration of oceanic basalts is well established (e.g., Hart and Staudigel, 1986). Because the enrichment in $\mathrm{U} / \mathrm{Pb}$ is relatively recent $(110 \mathrm{Ma})$, little ${ }^{235} \mathrm{U}$ is present relative to ${ }^{238} \mathrm{U}$, and therefore ${ }^{206} \mathrm{~Pb}$ has increased much more rapidly than ${ }^{207} \mathrm{~Pb}$. Because little or no Th is added during alteration, ${ }^{232} \mathrm{Th} /{ }^{238} \mathrm{U}$ is low $(0.56)$ compared with relatively unaltered basalts from this site $\left({ }^{232} \mathrm{Th} /{ }^{238} \mathrm{U} \cong 2.5\right)$, and ${ }^{206} \mathrm{~Pb}$ has increased more rapidly than ${ }^{208} \mathrm{~Pb}$.

The effect of leaching the Site 843 samples is to decrease their present-day ${ }^{87} \mathrm{Sr} /{ }^{86} \mathrm{Sr}$ ratios (to $\approx 0.7027$ ) and increase their ${ }^{143} \mathrm{Nd} /$ ${ }^{144} \mathrm{Nd}$ ratios (to $\approx 0.51317$ ) to values typical of fresh EPR MORB (Fig.11). Age correction of ${ }^{87} \mathrm{Sr} /{ }^{86} \mathrm{Sr}$ and ${ }^{143} \mathrm{Nd} /{ }^{144} \mathrm{Nd}$ ratios of the leached samples to $110 \mathrm{Ma}$ results in little change in ${ }^{87} \mathrm{Sr} /{ }^{86} \mathrm{Sr}$ ratios but lowers ${ }^{143} \mathrm{Nd} / 144 \mathrm{Nd}$ ratios (to 0.51296 , or $\varepsilon_{\mathrm{Nd}}=+9.0$; Fig. 11) and, in effect, decreases their total range to within the analytical uncertainty $( \pm 0.00001$; Table 4$)$. The ${ }^{87} \mathrm{Sr} /{ }^{86} \mathrm{Sr}$ of the mantle source of 


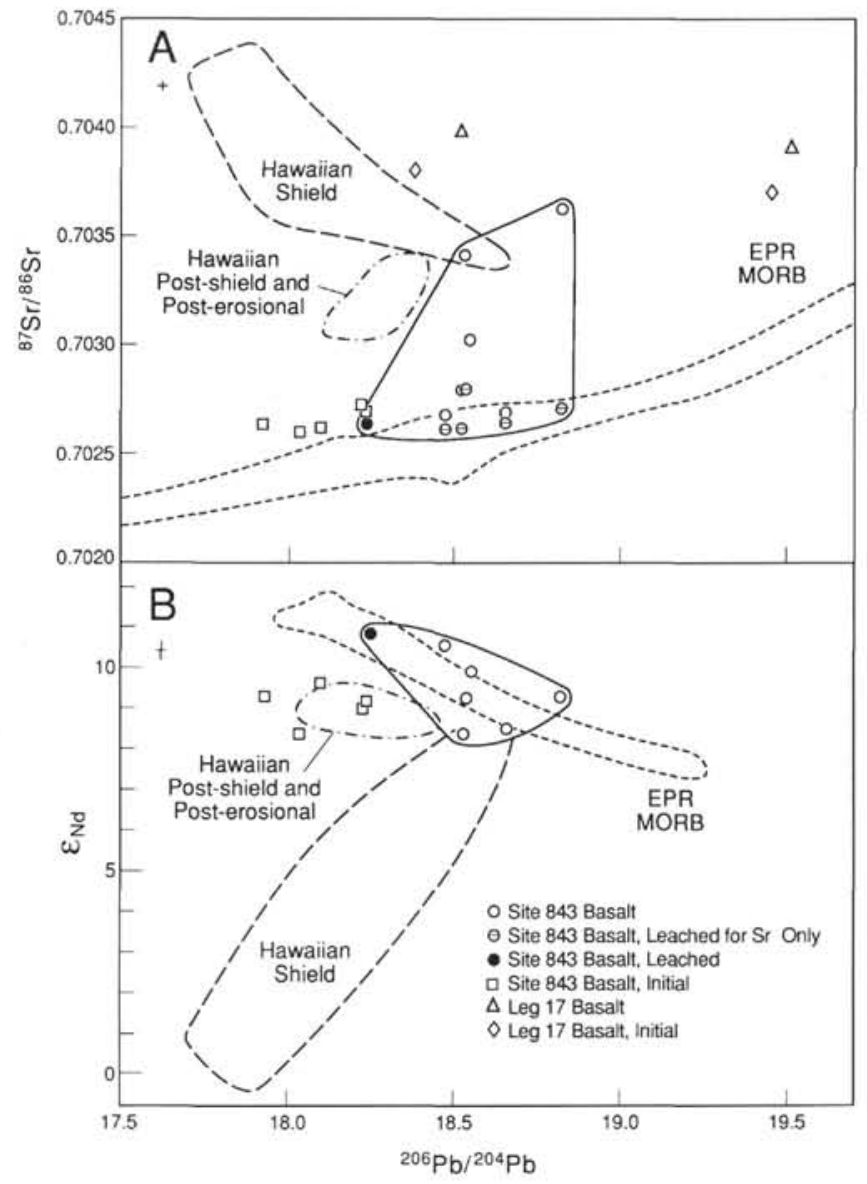

Figure 10. A. Plot of ${ }^{87} \mathrm{Sr} /{ }^{86} \mathrm{Sr} v s .{ }^{206} \mathrm{~Pb} /{ }^{204} \mathrm{~Pb}$. Two Cretaceous Pacific MORB samples from DSDP Leg 17 are shown for comparison. B. Plot of $\varepsilon_{\mathrm{Nd}} \mathrm{vs}$. ${ }^{206} \mathrm{~Pb} /{ }^{204} \mathrm{~Pb}$. Error bars in upper left corners are $\pm 2 \sigma$, and apply to all Site 843 basalt isotope ratios except initial $\mathrm{Pb}$ ratios (see text). Data sources for fields and for Leg 17 basalt isotope ratios given in the caption of Figure 9.

MORB evolves very slowly, due to both the long half-life of ${ }^{87} \mathrm{Rb}$ and the low $\mathrm{Rb} / \mathrm{Sr}$ of the MORB source. Thus, the ${ }^{87} \mathrm{Sr} /{ }^{86} \mathrm{Sr}$ in the mantle has not changed significantly since the early Phanerozoic (e.g., Jacobsen and Wasserburg, 1979). An average ${ }^{143} \mathrm{Nd} /{ }^{144} \mathrm{Nd}$ ratio of $0.51299\left(\varepsilon_{\mathrm{Nd}}=+9.6\right)$ is calculated for the mantle source of MORB at $110 \mathrm{Ma}$ based on a present-day MORB average ${ }^{143} \mathrm{Nd} /{ }^{144} \mathrm{Nd}$ of 0.51316 and average ${ }^{147} \mathrm{Sm} /{ }^{144} \mathrm{Nd}$ of 0.237 (e.g., Taylor et al., 1983). Thus, $\mathrm{Sr}$ and Nd isotopes in the Site 843 lavas are consistent with derivation from a Cretaceous MORB source.

Initial $\mathrm{Pb}$ ratios (Table 4) are only roughly estimated for the Site 843 lavas, unlike initial Nd or Sr ratios, because parent/daughter ratios are calculated based on $\mathrm{U}$ and Th abundances obtained from ICP-MS measurements on whole-rock powders rather than from the isotope dilution measurements on acid-washed, hand-picked small chips used to obtain $\mathrm{Rb}, \mathrm{Sr}, \mathrm{Sm}, \mathrm{Nd}$, and $\mathrm{Pb}$ abundances and isotopic compositions. Cumulative errors in the initial ratios due to using abundance data from both isotope dilution and ICP-MS are estimated as \pm 0.15 for ${ }^{206} \mathrm{~Pb} /{ }^{204} \mathrm{~Pb}, \pm 0.02$ for ${ }^{207} \mathrm{~Pb} /{ }^{204} \mathrm{~Pb}$, and \pm 0.11 for ${ }^{208} \mathrm{~Pb} /{ }^{204} \mathrm{~Pb}$.

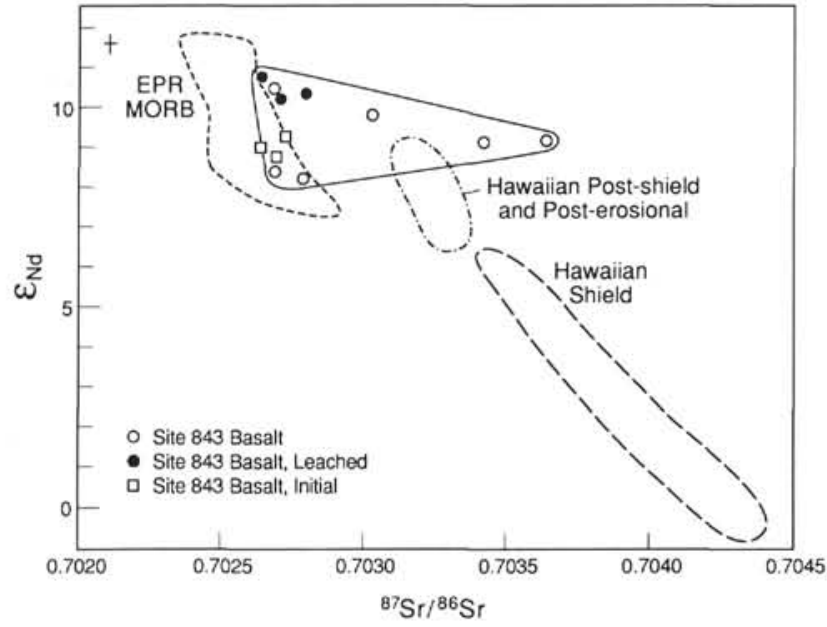

Figure 11. Plot of $\varepsilon_{\mathrm{Nd}}$ vs. $87 \mathrm{Sr} /{ }^{86} \mathrm{Sr}$. Error bars in upper left corner are $\pm 2 \sigma$. Data sources for fields given in the caption of Figure 9.

Errors in the initial ratios due to differences in sample preparation and analytical methods are not known. It is nonetheless worth noting that isotope systematics show a signature for the initial ratios of Site 843 lavas that appears lower in $\varepsilon_{\mathrm{Nd}}$ relative to ${ }^{206} \mathrm{~Pb} /{ }^{204} \mathrm{~Pb}$, and appears higher in ${ }^{208} \mathrm{~Pb} /{ }^{204} \mathrm{~Pb}$ and ${ }^{207} \mathrm{~Pb} /{ }^{204} \mathrm{~Pb}$ relative to ${ }^{206} \mathrm{~Pb} /{ }^{204} \mathrm{~Pb}$, in comparison with present-day EPR MORB (Figs. 9 and 10) or $110 \mathrm{Ma}$ MORB. Initial ratios of ${ }^{208} \mathrm{~Pb} /{ }^{204} \mathrm{~Pb}-{ }^{206} \mathrm{~Pb} /{ }^{204} \mathrm{~Pb}$ and $\varepsilon_{\mathrm{Nd}}{ }^{206} \mathrm{~Pb} /{ }^{204} \mathrm{~Pb}$ plot mostly outside the projected range of $110 \mathrm{Ma}$ Southeast Pacific MORB (assuming $\mu \cong 8$ ) and near present-day ratios of Hawaiian lavas, possibly suggesting an enriched component for the source of the Site 843 basalts (Figs. 9 and 10). The evolution of the mantle source of Hawaiian lavas is uncertain, and the MORB mantle source $\left(\mu \cong 8\right.$ ) has increased in ${ }^{206} \mathrm{~Pb} /{ }^{204} \mathrm{~Pb}$ in $110 \mathrm{Ma}$. Thus, the observed enrichment of the Site 843 basalts is dependent on the accuracy of the age correction of their $\mathrm{Pb}$ ratios.

\section{Oxygen Isotopes}

Four samples that were analyzed for radiogenic isotopes also were analyzed for oxygen isotope ratios (Table 4). Their $\delta^{18} \mathrm{O}$ values range from $+6.4 \%$ to $+8.7 \%$. Fresh EPR N-MORB glasses have an average $\delta^{18} \mathrm{O}$ of $+5.6 \pm 0.1 \%$ (Ito et al., 1987). The higher $\delta^{18} \mathrm{O}$ values for the Cretaceous-age MORB may have been caused by (1) post-eruptive exchange with seawater, (2) assimilation of seawater-altered basalt by the magma, (3) oxygen isotope fractionation during fractional crystallization and partial melting, and (4) source heterogeneity (Ito et al., 1987). Although none of these factors can be ruled out with certainty in the case of the Site 843 lavas, the primary cause of their enrichment relative to N-MORB is most likely low-temperature alteration by seawater, based on petrographic evidence. The sample with the lowest $\delta^{18} \mathrm{O}$, Sample 136-843B-1R-1, 61-63 cm, also has the lowest $\mathrm{K}_{2} \mathrm{O}$ content and a low initial ${ }^{87} \mathrm{Sr} /{ }^{86} \mathrm{Sr}$ ratio and shows little petrographic evidence of alteration, whereas the sample with the highest $\delta^{18} \mathrm{O}, 136-843 \mathrm{~B}-2 \mathrm{R}-2,77-79 \mathrm{~cm}$, has a high initial ${ }^{87} \mathrm{Sr} /{ }^{86} \mathrm{Sr}$ ratio and is the most visibly altered. This is consistent with the findings of Muehlenbachs (1979), who determined that in 103 whole-rock, Cretaceous MORB samples with a range in $\delta^{18} \mathrm{O}$ from $+6.0 \%$ to

Table 6. Basaltic magma crystal-liquid partition coefficient values used for fractional-crystallization modeling in Figure 7.

\begin{tabular}{llcccccccc}
\hline & $\mathrm{Th}$ & $\mathrm{Ta}$ & $\mathrm{Nb}$ & $\mathrm{Pb}$ & $\mathrm{P}$ & $\mathrm{Zr}$ & $\mathrm{Hf}$ & $\mathrm{Ti}$ & $\mathrm{Y}$ \\
\hline Olivine & 0.001 & 0.01 & 0.01 & 0.001 & 0.019 & 0.01 & 0.01 & 0.01 & 0.01 \\
Clinopyroxene & 0.01 & 0.01 & 0.01 & 0.05 & 0.017 & 0.1 & 0.1 & 0.3 & 0.4 \\
Plagioclase & 0.001 & 0.01 & 0.01 & 0.25 & 0.014 & 0.01 & 0.01 & 0.05 & 0.03 \\
\hline
\end{tabular}




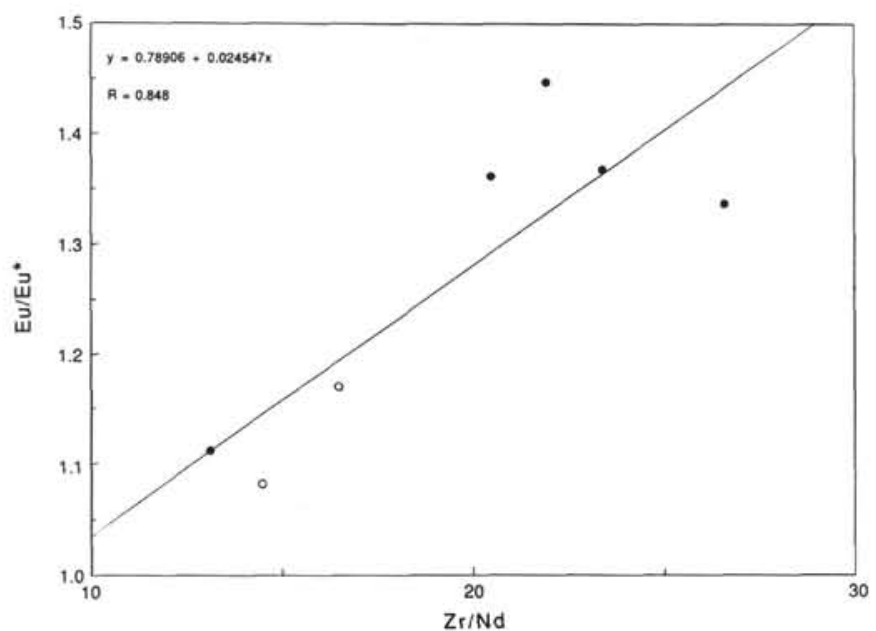

Figure 12. Plot of Eu/Eu* vs. $\mathrm{Zr} / \mathrm{Nd}$. Eu/Eu ${ }^{*}$ is a measure of the $\mathrm{Eu}$ anomaly, where $\mathrm{Eu}^{*}$ is the extrapolated Eu abundance taken between $\mathrm{Sm}$ and $\mathrm{Gd}$. Symbols are the same as those in Figure 3 .

$+26.4 \%$, and an original $\delta^{18} \mathrm{O} \cong+5.8 \%$, the highest enrichment in ${ }^{18} \mathrm{O}$ occurred in highly altered hyaloclastites, breccias, and flow margins. Although no calcite veins were observed in thin sections adjacent to whole-rock samples, it is worth noting that carbonates in veins in the Hole $843 \mathrm{~B}$ basalts have $\delta^{18} \mathrm{O}$ values of $+25.5 \%$, to $+30.5 \%$, (Alt, this volume), which would contribute greatly to ${ }^{18} \mathrm{O}$ enrichment in any whole-rock samples containing calcite veins.

\section{Implications for MORB Source}

Although the Site 843 basalts are similar to other Pacific MORB in major element composition and ${ }^{143} \mathrm{Nd} /{ }^{144} \mathrm{Nd}-{ }^{87} \mathrm{Sr} /{ }^{86} \mathrm{Sr}$ systematics, they are distinguished by their distinct positive Eu anomaly, by their relative enrichment in HFSE, and by their very low $\mathrm{La} / \mathrm{Nb}$ and $\mathrm{Ba} / \mathrm{Nb}$ ratios. Were these geochemical features derived from the Cretaceous mantle source for MORB?

The Eu anomaly increases in magnitude with decreasing sample REE concentration (Fig. 6). Because analytical error also increases with decreasing concentration, we compared the Site 843 REE patterns with that of another light-REE-depleted, Cretaceous Pacific MORB analyzed by ICP-MS in the same lab. Comparison with DSDP Sample 16-163-29-2, 87-89 cm, shows that analytical error is not the cause of the Eu anomaly observed in the Site 843 samples (Fig. 6).

The simplest explanation for a positive Eu anomaly is assimilation of plagioclase. This is unlikely, however, because the lavas contain only rare $(<0.1 \mathrm{vol} \%)$ plagioclase phenocrysts, and the phenocrysts that are present are euhedral. There is no correlation between the Eu anomaly and major elements that would be indicative of plagioclase control (e.g., $\mathrm{Ca} / \mathrm{Al})$. However, there is a positive correlation between the Eu anomaly $\left(\mathrm{Eu} / \mathrm{Eu}^{*}\right.$, where $\mathrm{Eu}^{*}$ is the extrapolated Eu abundance taken between $\mathrm{Sm}$ and $\mathrm{Gd}$ ) and $\mathrm{Zr} / \mathrm{Nd}$ (Fig. 12), indicating similar behavior of the elements Eu and $\mathrm{Zr}$ in the Leg 136 lavas. Eu is more compatible in plagioclase (the crystal-liquid partition coefficient $K_{d}$ $=0.32 ;$ Henderson, 1986) than is $\mathrm{Zr}\left(K_{d} \cong 0.01\right.$; Table 6$) . \mathrm{Zr}$ would not be expected to increase relative to $\mathrm{Nd}$ with addition of plagioclase. Eu in rock may be remobilized by water only when reduced to its $\mathrm{Eu}^{2+}$ valence state, and its redeposition in its more common trivalent state would be expected only under highly oxidizing conditions (MacRae et al., 1992). $\mathrm{Zr}$ is a HFSE that is not usually susceptible to mobility during low-temperature seawater alteration. The similarity in behavior between Eu and $\mathrm{Zr}$ cannot be explained by plagioclase assimilation or by low-temperature seawater alteration. The most likely explanation for the positive Eu anomaly is that it is a characteristic of the mantle source for these basalts. Similar positive Eu anomalies have been observed in some OIB (e.g., Tasmantid Seamounts; Eggins et

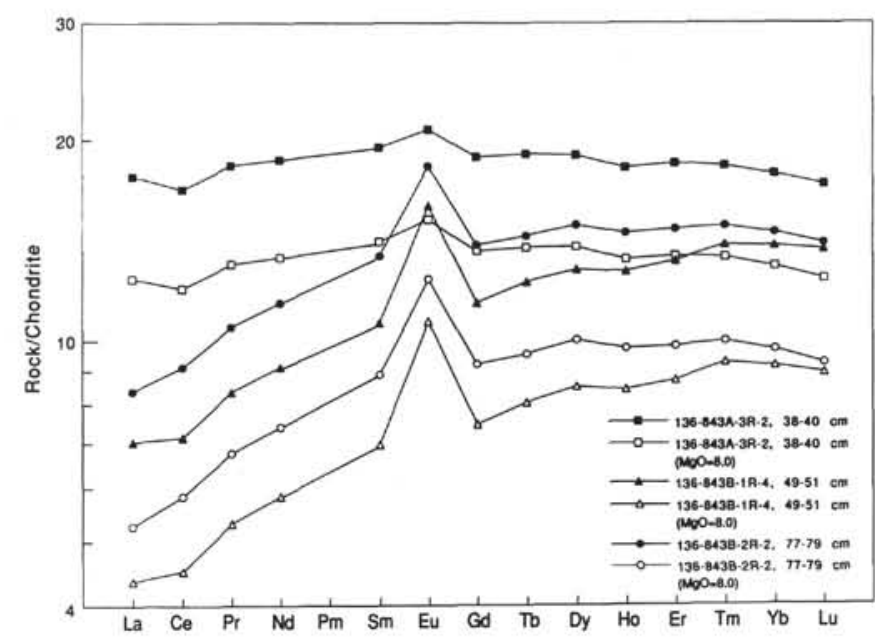

Figure 13. Chondrite-normalized REE diagram for representative Site 843 basalt samples and patterns of the same samples corrected for fractional crystallization to $\mathrm{MgO}=8.0 \mathrm{wt} \%$. See text for explanation. Chondrite normalization values from Boynton (1984).

al., 1991; Lanai, Hawaii; West et al., 1992), and in a few MORB (e.g., Jenner and Hertogen, 1986) and EPR near-axis seamount lavas (e.g., Bender et al., 1984; Fornari et al., 1988).

To evaluate the size of the Eu anomaly in the parental magmas for the Site 843 basalts, a crystal fractionation model for Pacific MORB was used to correct the REE concentrations of the Site 843 lavas to those of a lava with an $\mathrm{MgO}$ content of $8.0 \mathrm{wt} \%$ (Y. Niu, 1992, and unpubl. data). The fractions of olivine, plagioclase, and clinopyroxene crystallized, as well as the fraction of melt remaining, were calculated from the $\mathrm{MgO}$ values of representative Site 843 basalt samples. The fraction of melt remaining, and bulk distribution coefficients calculated for the REE from the basaltic magma partition coefficients for the elements in the minerals (Henderson, 1986), were then used in the Rayleigh fractional crystallization equation,

$$
C_{o}=C_{l} / F^{(D-l)},
$$

(Neumann et al., 1954) where $C_{o}$ is the concentration of the element in the source or parent melt (i.e., at $\mathrm{MgO}=8.0 \mathrm{wt} \%$ ), $C_{l}$ is the concentration of the element in the melt after fractional crystallization (i.e., measured in the rock), $F$ is the fraction of melt remaining after fractional crystallization, and $D$ is the bulk distribution coefficient of the element in the minerals that crystallized. Figure 13 shows that correcting the REE to $\mathrm{MgO}=8.0 \mathrm{wt} \%$ reduces the concentrations of the REE in the samples, but the overall chondrite-normalized patterns retain the same shape. The Eu anomalies are slightly larger at $\mathrm{MgO}=$ $8.0 \mathrm{wt} \%$, which is to be expected, because plagioclase crystallization preferentially removes Eu from the melt in an amount 3 or 4 times that of Gd and Sm (Henderson, 1986).

There is no petrographic or chemical evidence for plagioclase assimilation. Furthermore, there is no known mechanism by which partial melting could create such an anomaly and still maintain the same overall REE pattern (e.g., West et al., 1992). Seawater alteration has been found to create Eu anomalies and to change $(\mathrm{La} / \mathrm{Sm})_{\mathrm{N}}$ ratios in lavas from the Troodos ophiolite, but the degree of alteration required to do this (Gillis et al., 1992) far exceeds that observed in the Site 843 lava samples. In addition, seawater alteration could not explain the correlation of $\mathrm{Eu} / \mathrm{Eu}^{*}$ with $\mathrm{Zr} / \mathrm{Nd}$ (Fig. 12). Therefore, the mantle source of the Site 843 basalts most likely was enriched in Eu relative to the other REE.

Using the same crystal fractionation model described above, the concentrations of the incompatible elements shown in the N-MORB normalization diagram (Fig. 7A) were corrected to those of a lava with an $\mathrm{MgO}$ content of $8.0 \mathrm{wt} \%$. Partition coefficients for the ele- 
ments in olivine, clinopyroxene, and plagioclase are appropriate for basaltic magmas and are taken from Henderson (1986) and Table 6. Figure 7B shows the results of correction for fractional crystallization. Enrichments are seen in $\mathrm{U}, \mathrm{Ta}, \mathrm{Nb}$, and $\mathrm{K}$ relative to $\mathrm{N}-\mathrm{MORB}$. In addition, the REE are depleted relative to N-MORB and to the elements $\mathrm{Sr}, \mathrm{P}, \mathrm{Zr}$, Ti, and possibly $\mathrm{Hf}$.

The crystal fractionation modeling shows that the apparent enrichments in $\mathrm{Ba}, \mathrm{Th}, \mathrm{Sr}, \mathrm{P}, \mathrm{Zr}, \mathrm{Hf}$, and $\mathrm{Ti}$ relative to $\mathrm{N}-\mathrm{MORB}$ observed in Figure 7A are the result of fractional crystallization of a parent melt with the unusual N-MORB-normalized trace element patterns of Figure 7B. The trace element patterns in Figure 7B cannot be readily explained by either alteration (because $\mathrm{Ta}, \mathrm{Nb}, \mathrm{Zr}, \mathrm{Ti}$, and $\mathrm{Hf}$ are immobile in seawater) or by partial melting processes (because these elements are similar in their degree of incompatibility). Thus, the mantle source of the Site 843 basalts must be enriched in $\mathrm{Ta}, \mathrm{Nb}$, and possibly $\mathrm{U}$ and $\mathrm{K}$ relative to $\mathrm{N}-\mathrm{MORB}$ and depleted in the REE relative to N-MORB and to the elements $\mathrm{Zr}$, Ti, and possibly $\mathrm{Sr}, \mathrm{P}$, and $\mathrm{Hf}$. In addition, the low $\mathrm{Ba} / \mathrm{Nb}$ and $\mathrm{La} / \mathrm{Nb}$ ratios are essentially unchanged by the correction for crystal fractionation, suggesting that the unique $\mathrm{Ba} / \mathrm{Nb}-\mathrm{La} / \mathrm{Nb}$ systematics are also characteristic of the mantle source of the Site 843 basalts.

Bienvenu et al. (1990) found that, in highly altered oceanic basalts, normalized REE concentrations are decreased relative to normalized concentrations of $\mathrm{Zr}, \mathrm{Nb}, \mathrm{Hf}$, and $\mathrm{Ta}$, due to the immobility of the latter elements during seawater alteration. Normalized Eu concentrations were found to be lower than normalized $\mathrm{Sm}$ concentrations in altered basalts, compared with fresh basalts from the same DSDP hole, which have $\mathrm{Eu}_{\mathrm{N}}=\mathrm{Sm}_{\mathrm{N}}$. These patterns are not observed in Site 843 basalts (Fig. 6). Site 843 lavas are depleted in REE relative to $\mathrm{Nb}$ and $\mathrm{Zr}$, and in some cases $\mathrm{Hf}$ and $\mathrm{Ta}$ (Fig. 7), but the difference in normalized concentration between the REE and the HFSE Nb, Zr, Hf, and Ta does not increase with increasing alteration. Sample 136$843 \mathrm{~B}-2 \mathrm{R}-2,77-79 \mathrm{~cm}$, is the most altered sample, yet it is not the sample most enriched in $\mathrm{Ta}$ or $\mathrm{Nb}$ relative to the REE. Sample 136$843 \mathrm{~B}-2 \mathrm{R}-2,77-79 \mathrm{~cm}$, is not significantly more depleted in the REE relative to $\mathrm{Zr}$ or $\mathrm{Nb}$ than is Sample 136-843B-1R-1, 61-63 cm. The latter is a much fresher sample, based on petrography, ${ }^{87} \mathrm{Sr} /{ }^{86} \mathrm{Sr}$ ratios, and $\delta^{18} \mathrm{O}$ values (Table 4).

The lower $\mathrm{Y} / \mathrm{Nb}$ and $\mathrm{Zr} / \mathrm{Nb}$ ratios (Fig. 5) of the Hole 843A lavas and their higher concentrations of HFSE (Fig. 7) and of light and middle REE relative to Hole $843 \mathrm{~B}$ lavas (Fig. 6) suggest an enriched component in the source of the Hole 843A T-MORB. A lower degree of partial melting for the Hole $843 \mathrm{~A}$ basalts is suggested because Hole $843 \mathrm{~A}$ lavas are isotopically indistinguishable from Hole $843 \mathrm{~B}$ lavas, and thus both probably have a common mantle source. This hypothesis is strongly supported by trace element behavior, but is not borne out by $\mathrm{CaO} / \mathrm{Al}_{2} \mathrm{O}_{3}$ ratios, which, for Hole $843 \mathrm{~A}$, range from 0.55 to 0.73 . The latter value is typical of Hole $843 \mathrm{~B}$ lavas. Both N-MORB (REE) and T-MORB $\left(\mathrm{K}_{2} \mathrm{O}, \mathrm{K} / \mathrm{P}, \mathrm{K} / \mathrm{Ti}, \mathrm{Y} / \mathrm{Nb}, \mathrm{Zr} / \mathrm{Nb}\right)$ chemical features characterize Hole $843 \mathrm{~B}$ lavas. Major element chemistry and initial $\varepsilon_{\mathrm{Nd}}{ }^{87} \mathrm{Sr} /{ }^{86} \mathrm{Sr}$ ratios for lavas from both holes indicate a Cretaceous MORB source, with initial ${ }^{208} \mathrm{~Pb} /{ }^{204} \mathrm{~Pb}-{ }^{206} \mathrm{~Pb} /{ }^{204} \mathrm{~Pb}$ and $\varepsilon_{\mathrm{Nd}}{ }^{206} \mathrm{~Pb} /{ }^{204} \mathrm{~Pb}$ systematics suggesting an enriched component in the mantle source of these basalts (Figs. 9, 10, and 11).

\section{Are Site 843 Basalts Representative of the Oceanic Crust Near Hawaii?}

The significance of the results of this study to Hawaiian magma evolution is dependent upon whether the lavas recovered from Holes $843 \mathrm{~A}$ and $843 \mathrm{~B}$ are representative of the oceanic crust under the Hawaiian Islands. We considered two possibilities for the origin of the Site 843 basalts: (1) a seamount, and (2) oceanic crust generated at a mid-ocean ridge.

A possible seamount origin for the Site 843 basalts is suggested by enrichment in incompatible elements relative to N-MORB, low $\mathrm{Y} / \mathrm{Nb}$ and $\mathrm{Zr} / \mathrm{Nb}$ ratios, and the location of Site 843 on a small ridge.
The South Hawaiian Seamount province includes many seamounts near Site 843 , but based on ${ }^{40} \mathrm{Ar} /{ }^{39} \mathrm{Ar}$ and $\mathrm{K}$-Ar dating, these seamounts are 20-30 Ma younger than basalts recovered at Site 843 (Waggoner, this volume). An origin as near-axis or axial seamounts may not be eliminated on the basis of age. However, the low, elongate nature of the hill drilled at Site 843 is not typical of seamount morphology. It is oriented parallel to the regional abyssal hill fabric identified in the site survey (Collins et al., 1992), and, therefore, could be a tectonic feature unrelated to seamount eruptions.

T-MORB from the EPR are commonly enriched in $\mathrm{K}, \mathrm{Nb}, \mathrm{Th}, \mathrm{Ba}$, $\mathrm{Rb}, \mathrm{Ta}$, and light REE relative to N-MORB from the same location (Sinton et al., 1991; Sinton and Niu, 1991; J. Sinton, pers. comm., 1993). Thus, while Site 843 basalts have some unusual geochemical characteristics, they are not distinguishable from either EPR T-MORB or seamount lavas on the basis of many incompatible element enrichments relative to N-MORB. Near-axis seamount lavas are not always geochemically different from MORB, but in some cases the seamount lavas are more primitive (Fornari et al., 1988). The freshest Site 843 rocks have $\mathrm{CaO} / \mathrm{Al}_{2} \mathrm{O}_{3}$ ratios of $0.76-0.79$ (average for all samples is $0.73)$, which is typical of the global range of MORB $(0.7-0.9$; Klein and Langmuir, 1987). Off-axis seamounts formed by low degrees of partial melting and showing trace element enrichments commonly have $\mathrm{CaO} / \mathrm{Al}_{2} \mathrm{O}_{3}$ ratios less than 0.65 (Niu and Batiza, 1991).

In summary, the morphology of Site 843 is indicative of an abyssal hill rather than a seamount, and the geochemical data do not allow us to discriminate between a seamount vs. a mid-ocean ridge origin for the basalts recovered. We conclude that these basalts are representative of the oceanic crust near Hawaii. It should be noted that both N-MORB and T-MORB are probably present in the Central Pacific oceanic crust, just as they are found together at the EPR today, and the lavas sampled at Site 843 probably represent only a part of the total compositional range of the oceanic crust near the Hawaiian islands. Additional sampling is needed to test this hypothesis.

\section{Implications of Site 843 Basalts for Hawaiian Magma Evolution}

The relationship between Site 843 basalts and Hawaiian lavas is illustrated most clearly in a plot of ${ }^{87} \mathrm{Sr} /{ }^{86} \mathrm{Sr}$ vs. ${ }^{206} \mathrm{~Pb} /{ }^{204} \mathrm{~Pb}$ (Fig. 10A). Previous studies concluded that the trend of the Hawaiian post-shield and post-erosional lavas could be explained by assimilation of a depleted-mantle end member from the low- ${ }^{87} \mathrm{Sr}{ }^{86} \mathrm{Sr}(0.7023)$, low${ }^{206} \mathrm{~Pb} /{ }^{204} \mathrm{~Pb}$ (17.7) end of the Pacific MORB trend (e.g., Clague and Frey, 1982; Chen and Frey, 1983, 1985; West et al., 1987). These studies are based on isotopic and trace element analyses of Hawaiian lavas and of zero-age, mostly Northern Hemisphere, EPR MORB. The lavas recovered at Site 843 do not have the low- ${ }^{87} \mathrm{Sr} /{ }^{86} \mathrm{Sr}$, low- $-{ }^{206} \mathrm{~Pb} /{ }^{204} \mathrm{~Pb}$ present-day isotopic composition required of an end member to explain the Hawaiian post-shield/post-erosional trend. The present-day isotope ratios are considered here because any interaction of Hawaiian magma would be with the Cretaceous crust and mantle through which it ascends. Other Cretaceous, Central Pacific MORB samples, from DSDPLeg 17, are likewise too high in ${ }^{87} \mathrm{Sr} /{ }^{86} \mathrm{Sr}$ and ${ }^{206} \mathrm{~Pb} /{ }^{204} \mathrm{~Pb}$ to serve as the depleted-mantle end member for the Hawaiian post-shield/posterosional lavas (Fig. 10A). It should be noted that the DSDP Leg 17 samples were not leached in acid before isotopic analysis, and that their high ${ }^{87} \mathrm{Sr} /{ }^{86} \mathrm{Sr}$ is probably due, in large part, to alteration (see Bass et al., 1973).

The oceanic basement surrounding the Hawaiian hot spot has experienced varying degrees of seawater alteration during the time since its formation in the Cretaceous. If the Site 843 basalts are representative of that basement, then Cretaceous basement typical of the area around the Hawaiian island chain would be expected to plot somewhere between the extremes of the lower ${ }^{-87} \mathrm{Sr} /{ }^{86} \mathrm{Sr}$ leached sample splits and the most altered unleached splits with their higher ${ }^{87} \mathrm{Sr} /{ }^{86} \mathrm{Sr}$ (field denoted by solid line in Fig. 10A). Lavas of this isotopic composition, ${ }^{87} \mathrm{Sr} /{ }^{86} \mathrm{Sr} \approx 0.7031$ and ${ }^{206} \mathrm{~Pb} /{ }^{204} \mathrm{~Pb} \approx 18.7$, could conceivably serve as 
the low- ${ }^{87} \mathrm{Sr} /{ }^{86} \mathrm{Sr}$, high- ${ }^{206} \mathrm{~Pb} /{ }^{204} \mathrm{~Pb}$ end member for the Hawaiian shield-building tholeiites. However, these altered rocks are probably only available in the upper portion of the oceanic lithosphere, where temperatures are low. This would greatly limit the amount of assimilation of crustal basalts that could occur in Hawaiian magmas. This simplistic model for Hawaiian tholeiite genesis would require extensive assimilation of oceanic crust and would also require that the mantle plume component for Hawaiian magmas be similar to the depleted mantle in its $\mathrm{Pb}$ isotopes but with low $\varepsilon_{\mathrm{Nd}}$ and high ${ }^{87} \mathrm{Sr} /{ }^{86} \mathrm{Sr}$.

The maximum amount of crustal assimilation that could occur for a typical Hawaiian volcano can be calculated by assuming a magma chamber with a diameter of $3 \mathrm{~km}$, which might shift laterally during the shield stage of volcanism to occupy an area of radius $3 \mathrm{~km}$ (e.g., Kilauea; Holcomb, 1987). We may then allow the area affected by the magma chamber to include an additional $1 \mathrm{~km}$ radius, or $4 \mathrm{~km}$ radius total, and assume assimilation can occur throughout the entire $5-\mathrm{km}$ thickness of oceanic crust. The volume of a cylinder of radius $4 \mathrm{~km}$ and height $5 \mathrm{~km}$ is about $250 \mathrm{~km}^{3}$. Taking Kohala on the island of Hawaii as an average Hawaiian volcano, with volume $14,000 \mathrm{~km}^{3}$ (Baragar and Jackson, 1974), the maximum assimilation of oceanic crust would then be $(250 / 14000) \times 100=1.8 \%$. In the case of a much larger volcano, Mauna Loa, the maximum assimilation is calculated as $0.6 \%$, assuming a volume of $42,000 \mathrm{~km}^{3}$ for Mauna Loa (Baragar and Jackson, 1974). These percentage values assume assimilation to be constant throughout the temporal evolution of the volcanoes. The maximum volume of oceanic crust that might be assimilated is insufficient to explain the observed isotopic composition of Hawaiian tholeiites. Either the mantle beneath the Hawaiian Islands is different from the source of the Site 843 basalts, or some other component is involved in shield lava genesis.

\section{SUMMARY AND CONCLUSIONS}

The moderately fractionated, Cretaceous seafloor basalts recovered from Holes 843A and 843B are mostly T-MORB, as indicated by their high $\mathrm{K}_{2} \mathrm{O}$ content, high $\mathrm{K} / \mathrm{Ti}$ and $\mathrm{K} / \mathrm{P}$ ratios, moderate $(\mathrm{La} / \mathrm{Sm})_{\mathrm{N}}$ ratios, and low $\mathrm{Y} / \mathrm{Nb}$ and $\mathrm{Zr} / \mathrm{Nb}$ ratios. Major element analyses show that the lavas have systematic trends on $\mathrm{MgO}$ variation diagrams only for $\mathrm{CaO}$ and $\mathrm{K}_{2} \mathrm{O}$. These petrographically similar rocks may be divided into two groups based on their trace element abundances and ratios: Hole 843A lavas and Hole 843B lavas. The Hole $843 \mathrm{~A}$ rocks are enriched in $\mathrm{Ti}, \mathrm{K}, \mathrm{Cr}, \mathrm{Sr}, \mathrm{Y}, \mathrm{Nb}, \mathrm{Ba}, \mathrm{Ta}, \mathrm{P}, \mathrm{Zr}$, and the light and middle REE relative to Hole 843B rocks.

The mantle source for the Site 843 basalts is characterized by enrichment in $\mathrm{U}, \mathrm{Ta}, \mathrm{Nb}$, and $\mathrm{K}$ relative to $\mathrm{N}-\mathrm{MORB}$ and by depletion in the REE relative to N-MORB and to the elements $\mathrm{Sr}, \mathrm{P}, \mathrm{Zr}$, Ti, and possibly Hf (Fig. 7B). The lavas possess a distinct positive Eu anomaly and very low $\mathrm{Ba} / \mathrm{Nb}$ and $\mathrm{La} / \mathrm{Nb}$ ratios. The low abundance $(<0.1$ vol\%) and euhedral form of plagioclase phenocrysts in the lavas argues against plagioclase assimilation as a cause for the Eu anomaly. Trace element modeling implies that fractional crystallization did not generate the Eu anomaly or the characteristic, normalized incompatible element patterns and trace element ratios of these basalts (Figs. 6,7 , and 13). The extreme degree of seawater alteration required to produce a positive Eu anomaly in basalts is not observed in the Site 843 lavas selected for this study. Furthermore, alteration cannot explain either the similar behavior of Eu and $\mathrm{Zr}$ in the rocks or the normalized concentrations of incompatible trace elements relative to $\mathrm{N}-\mathrm{MORB}$ and/or the REE, with the possible exceptions of $\mathrm{Ba}, \mathrm{Cs}$, $\mathrm{Rb}, \mathrm{Th}, \mathrm{U}, \mathrm{K}$, and $\mathrm{P}$. There is no known mechanism by which variable degrees of partial melting could create the observed trace element patterns or the low $\mathrm{Ba} / \mathrm{Nb}$ and $\mathrm{La} / \mathrm{Nb}$ ratios. Therefore, it is concluded that the mantle source of the Site 843 basalts was enriched in Ta and $\mathrm{Nb}$ and possibly $\mathrm{U}$ and $\mathrm{K}$ relative to $\mathrm{N}-\mathrm{MORB}$ and enriched in $\mathrm{Eu}$ relative to the other REE.

Isotopically, the Site 843 basalts are similar to present-day N-MORB from the Southern Hemisphere EPR. Varying degrees of low-temperature seawater alteration of the lavas are indicated by the higher $\delta^{18} \mathrm{O}$ values $(+6.4 \%$ to $+8.7 \%$ vs. $+5.6 \%$ for fresh EPR $\mathrm{N}-\mathrm{MORB}$ ) and ${ }^{87} \mathrm{Sr} /{ }^{86} \mathrm{Sr}$ ratios for unleached vs. leached samples (e.g., 0.70344 vs. 0.70282 ). The leached samples have initial ${ }^{87} \mathrm{Sr} /{ }^{86} \mathrm{Sr}$ ratios (0.70263-0.70275) within the range of fresh, unaltered N-MORB (i.e., $0.7024-0.7030)$. The $\varepsilon_{\mathrm{Nd}^{-}}{ }^{87} \mathrm{Sr} /{ }^{86} \mathrm{Sr}$ systematics of calculated initial ratios indicate that the Site 843 lavas were derived from a Cretaceous MORB source. Similar isotope ratios for lavas from both holes indicate that Hole $843 \mathrm{~A}$ and Hole $843 \mathrm{~B}$ basalts were derived from the same mantle source, with a lower degree of partial melting for the Hole $843 \mathrm{~A}$ lavas implied by lower $\mathrm{Y} / \mathrm{Nb}$ and $\mathrm{Zr} / \mathrm{Nb}$ ratios and higher concentrations of light and middle REE relative to Hole 843B lavas. An enriched component within the mantle source is suggested by the ${ }^{208} \mathrm{~Pb} /{ }^{204} \mathrm{~Pb}$ ${ }^{206} \mathrm{~Pb} /{ }^{204} \mathrm{~Pb}$ and $\varepsilon_{\mathrm{Nd}}{ }^{206} \mathrm{~Pb} /{ }^{204} \mathrm{~Pb}$ systematics of the initial ratios of the Site 843 basalts.

In addition to the geochemical characterization of the Site 843 lavas, a major goal of this study has been to evaluate the isotopic relationship of these oceanic crustal basalts to Hawaiian hot spot lavas. Previous studies, based on isotopic and trace element analyses of Hawaiian lavas and of zero-age MORB, concluded that the ${ }^{87} \mathrm{Sr} /{ }^{86} \mathrm{Sr}$ ${ }^{206} \mathrm{~Pb} /{ }^{204} \mathrm{~Pb}$ trend of the Hawaiian post-shield and post-erosional lavas could be explained by assimilation of a depleted-mantle end member from the low ${ }^{87} \mathrm{Sr}{ }^{86} \mathrm{Sr}(0.7023)$, low- ${ }^{206} \mathrm{~Pb} /{ }^{204} \mathrm{~Pb}(17.7)$ end of the Pacific MORB trend (e.g., Clague and Frey, 1982; Chen and Frey, 1983, 1985; West et al., 1987). Based on isotopic analyses of Site 843 basalts, it is concluded that these oceanic crustal basalts do not possess the low ${ }^{87} \mathrm{Sr} /{ }^{86} \mathrm{Sr}$, low ${ }^{206} \mathrm{~Pb} /{ }^{204} \mathrm{~Pb}$ isotopic composition required of an end member to explain the trend of the Hawaiian post-shield/ post-erosional lavas.

\section{ACKNOWLEDGMENTS}

We are grateful to John Mahoney and Khalil Spencer for the use of the isotope chemistry lab and mass spectrometer, and for helpful discussions. Thanks to Yaoling Niu for kindly sharing his Pacific MORB crystal fractionation program with us, and to John Mahoney, John Sinton, Paterno Castillo, and David Christie for their reviews of an early draft of this paper.

\section{REFERENCES"}

Baragar, K.E., and Jackson, E.D., 1974. Calculated volumes of individual shield volcanoes along the Hawaiian-Emperor Chain. J. Res. U.S. Geol. Surv., 2:545-550.

Bass, M.N., 1972. Occurrence of transitional abyssal basalt. Lithos, 5:57-67.

Bass, M.N., Moberly, R., Rhodes, J.M., Shih, C.S., and Church, S.E., 1973. Volcanic rocks cored in the central Pacific, Leg 17, Deep Sea Drilling Project. In Winterer, E.L., Ewing, J.I., et al., Init. Repts. DSDP, 17: Washington (U.S. Govt. Printing Office), 429-503.

Bender, J.F., Langmuir, C.H., and Hanson, G.N., 1984. Petrogenesis of basalt glasses from the Tamayo region, East Pacific Rise. J. Petrol., 25:213-254.

Bienvenu, P., Bougault, H., Joron, J.L., Treuil, M., and Dmitriev, L., 1990. MORB alteration: rare-earth element/non-rare-earth hygromagmaphile element fractionation. Chem. Geol., 82:1-14.

Borthwick, J., and Harmon, R.S., 1982. A note regarding $\mathrm{ClF}_{3}$ as an alternative to $\mathrm{BrF}_{5}$ for silicate oxygen isotope analysis. Geochim. Cosmochim. Acta. 46:1665-1668.

Boynton, W.V., 1984. Cosmochemistry of the rare earth elements: meteorite studies. In Henderson, P. (Ed.), Rare Earth Element Geochemistry: New York (Elsevier), 63-114.

Chen, C.-Y., and Frey, F.A., 1983. Origin of Hawaiian tholeiite and alkalic basalt. Nature, 302:785-789.

, 1985. Trace element and isotopic geochemistry of lavas from Haleakala volcano, East Maui, Hawaii: implications for the origin of Hawaiian basalts. J. Geophys. Res., 90:8743-8768.

\footnotetext{
Abbreviations for names of organizations and publications in ODP reference lists follow the style given in Chemical Abstracts Service Source Index (published by American Chemical Society).
} 
Clague, D.A., and Frey, F.A., 1982. Petrology and trace element geochemistry of the Honolulu volcanics, Oahu: implications for the oceanic mantle below Hawaii. J. Petrol., 23:447-504.

Clayton, R.N., and Mayeda, T.K., 1963. The use of bromine pentafluoride in the extraction of oxygen from oxides and silicates for isotopic analysis. Geochim. Cosmochim. Acta, 27:43-52.

Collins, J.A., Duennebier, F., and Shipboard Scientific Party, 1992. Site survey and underway geophysics. In Dziewonski, A., Wilkens, R., Firth, J., et al., Proc. ODP, Init. Repts., 136: College Station, TX (Ocean Drilling Program), 27-34.

Doherty, W., 1989. An internal standardization procedure for the determination of yttrium and the rare earth elements in geological materials by inductively coupled plasma mass spectrometry. Spectrochem. Acta, 44B:263-280.

Eggins, S.M., Green, D.H., and Falloon, T.J., 1991. The Tasmantid Seamounts: shallow melting and contamination of an EM1 mantle plume. Earth Planet. Sci. Lett., 107:448-462.

Fontignie, D., and Schilling, J.-G., 1991. ${ }^{87} \mathrm{Sr} /{ }^{86} \mathrm{Sr}$ and REE variations along the Easter Microplate boundaries (south Pacific): application of multivariate statistical analyses to ridge segmentation. Chem. Geol., 89:209-242.

Fornari, D.J., Perfit, M.R., Allan, J.F., Batiza, R., Haymon, R., Barone, A., Ryan, W.B.F., Smith, T., Simkin, T., and Luckman, M.A., 1988. Geochemical and structural studies of the Lamont seamounts: seamounts as indicators of mantle processes. Earth Planet. Sci. Lett., 89:63-83.

Garcia, M.O., Jorgenson, B., Mahoney, J., Ito, E., and Irving, A.J., 1993. An evaluation of temporal geochemical evolution of Loihi summit lavas: results from ALVIN submersible dives. J. Geophys. Res., 98:537-550.

Gillis, K.M., Ludden, J.N., and Smith, A.D., 1992. Mobilization of REE during crustal aging in the Troodos Ophiolite, Cyprus. Chem. Geol., 98:71-86.

Gladney, E.S., and Roelandts, I., 1988. 1987 Compilation of elemental concentration data from U.S. Geological Survey BHVO-1, MAG-1, QLD-1, RGM-1, SCo-1, SGR-1 and STM-1. Geostand. Newsl., 12:253-362.

Govindaraju, K., 1989. 1989 compilation of working values and sample description for 272 geostandards. Geostand. Newsl., 13:1-113.

Hanan, B.B., and Schilling, J.-G., 1989. Easter Microplate evolution: $\mathrm{Pb}$ isotopic evidence. J. Geophys. Res., 94:7432-7448.

Hart, S.R., and Staudigel, H., 1986. Ocean crust vein mineral deposition: Rb/Sr ages, U-Th- $\mathrm{Pb}$ geochemistry, and duration of circulation at DSDP Sites 261, 462 and 516. Geochim. Cosmochim. Acta, 50:2751-2761.

Henderson, P.H., 1986. Inorganic Geochemistry: Oxford (Pergamon Press).

Hofmann, A.W., 1988. Chemical differentiation of the Earth: the relationship between mantle, continental crust, and oceanic crust. Earth Planet. Sci. Lett., 90:297-314.

Holcomb, R.T., 1987. Eruptive history and long-term behavior of Kilauea volcano. In Decker, R.W., Wright, T.L., and Stauffer, P.H. (Eds.), Volcanism in Hawaii. Geol. Surv. Prof. Pap. U.S., 1350:261-350.

Honnorez, J., 1981. The aging of the oceanic crust at low temperature. In Emiliani, C. (Ed.), The Sea (Vol. 7): The Oceanic Lithosphere: New York (Wiley), 525-587.

Ito, E., White, W.M., and Göpel, C., 1987. The O, Sr, Nd and $\mathrm{Pb}$ isotope geochemistry of MORB. Chem. Geol., 62:157-176.

Jacobsen, S.B., and Wasserburg, G.J., 1979. Nd and Sr isotopic study of the Bay of Islands Ophiolite Complex and the evolution of the source of mid-ocean ridge basalts. J. Geophys. Res., 84:7429-7445.

Jenner, G.A., and Hertogen, J., 1986. Constraints on processes affecting the origin of oceanic crust: geochemical evidence from the 0-35 M.Y. age basalts, between $30^{\circ} \mathrm{N}$ and $40^{\circ} \mathrm{N}$, MAR. J. Geodyn., 5:49-78.

Klein, E.M., and Langmuir, C.H., 1987. Global correlations of ocean ridge basalt chemistry with axial depth and crustal thickness. J. Geophys. Res., 92:8089-8115.

Macdougall, J.D., and Lugmair, G., 1986. Sr and Nd isotopes in basalts from the East Pacific Rise: significance for mantle heterogeneity. Earth Planet. Sci. Lett., 77:273-284.

MacRae, N.D., Nesbitt, H.W., and Kronberg, B.I., 1992. Development of a positive Eu anomaly during diagenesis. Earth Planet. Sci. Lett., 109:585-591.

Mahoney, J., 1987. An isotopic survey of Pacific oceanic plateaus: implications for their nature and origin. In Keating, B.H., Fryer, P., Batiza, R., and Boehlert, G.W. (Eds.), Seamounts, Islands, and Atolls. Am. Geophys. Union Monogr., 43:207-220

Mahoney, J., Nicollet, C., and Dupuy, C., 1991. Madagascar basalts: tracking oceanic and continental sources. Earth Planet. Sci. Lett., 104:350-363.

Muehlenbachs, K., 1979. The alteration and aging of the basaltic layer of the sea floor: oxygen isotope evidence from DSDP/IPOD Legs 51, 52, and 53.
In Donnelly, T., Francheteau, J., Bryan, W., Robinson, P., Flower, M., Salisbury, M., et al., Init. Repts. DSDP, 51, 52, 53 (Pt. 2): Washington (U.S. Govt. Printing Office), 1159-1167.

Neumann, H., Mead, J., and Vitaliano, C.J., 1954. Trace element variations during fractional crystallization as calculated from the distribution law. Geochim. Cosmochim. Acta, 6:90-99.

Niu, Y., 1992. Mid-ocean ridge magmatism: style of mantle upwelling, partial melting, crustal level processes, and spreading rate dependence-a petrologic approach [Ph.D. dissert.]. Univ. of Hawaii, Manoa.

Niu, Y., and Batiza, R., 1991. An empirical method for calculating melt compositions produced beneath mid-ocean ridges: application for axis and off-axis (seamounts) melting. J. Geophys. Res., 96:21753-21777.

Norrish, K., and Chappell, B., 1977. X-ray fluorescence spectrometry. In Zussman, J. (Ed.), Physical Methods in Determinative Mineralogy: New York (Academic Press), 201-272.

Norrish, K., and Hutton, J.T., 1969. An accurate X-ray spectrographic method for the analysis of a wide range of geological samples. Geochim. Cosmochim. Acta, 33:431-453.

Price, R.C., Gray, C.M., Wilson, R.E., Frey, F.A., and Taylor, S.R., 1991. The effects of weathering on rare earth element, yttrium and barium abundances in Tertiary basalts from southeastern Australia. Chem. Geol., 93:245-265.

Pringle, M.S., Jr., 1992. Geochronology and petrology of the Musicians Seamounts, and the search for hot spot volcanism in the Cretaceous Pacific [Ph.D. dissert.]. Univ. of Hawaii, Manoa.

Schilling, J.-G., 1975. Rare-earth variations across "normal segments" of the Reykjanes Ridge, $60^{\circ}-53^{\circ} \mathrm{N}$, Mid-Atlantic Ridge, $29^{\circ} \mathrm{S}$, and East Pacific Rise, $2^{\circ}-19^{\circ} \mathrm{S}$, and evidence on the composition of the underlying lowvelocity layer. J. Geophys. Res., 80:1459-1473.

Shipboard Scientific Party, 1992a. Explanatory notes. In Dziewonski, A., Wilkens, R., Firth, J., et al., Proc. ODP, Init. Repts., 136: College Station, TX (Ocean Drilling Program), 9-26.

1992b. Site 843. In Dziewonski, A., Wilkens, R., Firth, J., et al., Proc. ODP, Init. Repts., 136: College Station, TX (Ocean Drilling Program), 65-99.

Sinton, J.M., and Niu, Y., 1991. Recent mantle enrichment and melting processes in the Hump region: EPR $18^{\circ}-19^{\circ} \mathrm{S}$. Eos, 72:507.

Sinton, J.M., Smaglik, S.M., Mahoney, J.J., and MacDonald, K.C., 1991. Magmatic processes at superfast spreading mid-ocean ridges: glass compositional variations along the East Pacific Rise $13^{\circ}-23^{\circ} \mathrm{S}$. J. Geophys. Res., 96:6133-6155.

Sun, S.-S., Nesbitt, R.W., and Sharaskin, A.Y., 1979. Geochemical characteristics of mid-ocean ridge basalts. Earth Planet. Sci. Lett., 44:119-138.

Taylor, S.R., McLennan, S.M., and McCulloch, M.T., 1983. Geochemistry of loess, continental crustal composition and crustal model ages. Geochim. Cosmochim. Acta, 47:1897-1905.

Thompson, G., 1983. Basalt-seawater interaction. In Rona, P.A., Boström, K., Laubier, L., and Smith, K.L. (Eds.), Hydrothermal Processes at Seafloor Spreading Centers: New York (Plenum Press), 225-278.

Todt, W., Cliff, R.A., Hanser, A., and Hofmann, A.W., $1984 .{ }^{202} \mathrm{~Pb}$ and ${ }^{205} \mathrm{~Pb}$ double spike for lead isotopic analyses. Terra Cognita, 4:209.

Waggoner, D.G., 1989. An isotopic and trace element study of mantle heterogeneity beneath the Norwegian-Greenland Sea [Ph.D. dissert.]. Univ. of Rhode Island, Kingston.

Weaver, B.L., Wood, D.A., Tarney, J., and Joron, J.L., 1986. Role of subducted sediment in the genesis of ocean-island basalts: geochemical evidence from South Atlantic islands. Geology, 14:275-278.

West, H.B., Garcia, M.O., Gerlach, D.C., and Romano, J., 1992. Geochemistry of tholeiites from Lanai, Hawaii. Contrib. Mineral Petrol., 112:520-542.

West, H.B., Gerlach, D.C., Leeman, W.P., and Garcia, M.O., 1987. Isotopic constraints on the origin of Hawaiian lavas from the Maui Volcanic Complex, Hawaii. Nature, 330:216-220.

West, H.B., and Leeman, W.P., 1987. Isotopic evolution of lavas from Haleakala Crater, Hawaii. Earth Planet. Sci. Lett., 84:211-225.

White, W.M., Hofmann, A.W., and Puchelt, H., 1987. Isotope geochemistry of Pacific mid-ocean ridge basalt. J. Geophys. Res., 92:4881-4893.

Wilson, M., 1989. Igneous Petrogenesis: A Global Tectonic Approach: London (Unwin Hyman).

Date of initial receipt: 23 November 1992

Date of acceptance: 1 June 1993

Ms 136SR-211 